\title{
Solidification Microsegregation and Hot Ductility of Fe-Mn-C-Al-xNb TWIP Steels
}

\author{
MIN HYEOK KWON, JIN-KYUNG KIM, JIAN BIAN, HARDY MOHRBACHER, \\ TAEJIN SONG, SUNG KYU KIM, and BRUNO C. DE COOMAN
}

The influence of $\mathrm{Nb}$ addition on casting microstructures and high-temperature mechanical properties of Fe-Mn-C-Al-xNb TWIP steels was analyzed by phase-field modeling and experiments. Phase-field simulations showed that $\mathrm{Mn}, \mathrm{Nb}$, and $\mathrm{C}$ are enriched in inter-dendritic regions while $\mathrm{Al}$ is enriched in dendritic regions during solidification process of the investigated TWIP steels. Both phase-field simulations and microstructural characterization show that NbC precipitates are preferentially present near inter-dendritic boundaries. $\mathrm{Nb}$ addition slightly reduces hot ductility of the investigated steel at $1173 \mathrm{~K}\left(900^{\circ} \mathrm{C}\right)$ while the $\mathrm{Nb}$-added TWIP steels show better hot-ductility than the reference steel for deformation temperatures above $1373 \mathrm{~K}\left(1100{ }^{\circ} \mathrm{C}\right)$. NbC precipitates and inter-dendritic distances appear to be the most important variables that affect hot-ductility behavior of the investigated TWIP steels.

https://doi.org/10.1007/s11661-018-4893-8

(c) The Minerals, Metals \& Materials Society and ASM International 2018

\section{INTRODUCTION}

HIGH Mn twinning-induced plasticity (TWIP) steel is a type of structural steel, characterized by both high strength and superior formability. ${ }^{[1-4]}$ Deformation twinning is known to be the main strain hardening enhancing mechanism in TWIP steels via the dynamic Hall-Petch effect. ${ }^{[5-7]}$ TWIP steels generally show a large strength-ductility balance, i.e., the product of ultimate tensile strength (UTS) and total elongation (TE), in excess of 50,000 MPa pct.

During straightening operation of continuous casting processes, casting defects such as transverse cracks are easily formed in steel. ${ }^{[8,9]}$ Hot ductility from high-temperature tensile tests can assess susceptibility to cracking during continuous casting. ${ }^{[8]}$ Hot ductility of TWIP steels has been an important focus of research due to high sensitivity of surface cracking in TWIP steels. ${ }^{[10-22]}$

MIN HYEOK KWON is with the Graduate Institute of Ferrous Technology, Pohang University of Science and Technology, Pohang, 37673, South Korea. JIN-KYUNG KIM is with the Graduate Institute of Ferrous Technology, Pohang University of Science and Technology and also with the Department of Energy Science, Sungkyunkwan University (SKKU), Suwon, 16419, Korea. Contact e-mail: j.k.kim@skku.edu JIAN BIAN is with the CBMM Asia PTE Ltd, Singapore, 049315, Singapore. HARDY MOHRBACHER is with the NiobelCon bvba, 2970, Schilde, Belgium. TAEJIN SONG and SUNG KYU KIM is with the Steel Products Research Group, Technical Research Laboratories, POSCO, Gwangyang, 57807, South Korea. BRUNO C. DE COOMAN is with the Graduate Institute of Ferrous Technology, Pohang University of Science and Technology and also with the NLMK Group, Moscow, Russia, 119017.

Manuscript submitted March 8, 2018.
In TWIP steels, reduced Mn concentration resulted in an increase in hot ductility. ${ }^{[10,17]}$ Bleck et al.${ }^{[10]}$ suggested that the wide solidification range of high $\mathrm{Mn}$ steels promoted micro-shrinkage and inter-dendritic segregation. Lan et al. ${ }^{[16]}$ reported that reduced matrix homogeneity by Mn micro-segregation and micro-porosity led to a decrease in hot ductility of a Fe-22Mn-0.6C (wt pct) TWIP steel. Kang et al. ${ }^{[12,18-22]}$ investigated the effect of various alloying elements such as $\mathrm{Al}, \mathrm{B}, \mathrm{Ti}, \mathrm{Nb}, \mathrm{V}, \mathrm{P}, \mathrm{N}$, and S on hot ductility of TWIP steels.

Micro-alloying has been considered as a way to increase strength of TWIP steels. ${ }^{[2-26]}$ Previous works reported increases of strength of TWIP steels by $\mathrm{Nb}$ addition. ${ }^{[24,26]} \mathrm{Nb}$ addition in TWIP steels also noticeably retards grain recrystallization as compared to micro-alloying with Ti or V. ${ }^{[25]}$ Mejia et al.$^{[15]}$ reported beneficial influence of $\mathrm{Nb}$ addition on the hot ductility of a Fe-21Mn-1.3Al-1.5Si-0.5C (wt pct) TWIP steel, particularly in a temperature range of $1073 \mathrm{~K}$ to $1173 \mathrm{~K}$ $\left(800{ }^{\circ} \mathrm{C}\right.$ to $900{ }^{\circ} \mathrm{C}$ ). However, the role of $\mathrm{Nb}$ addition in hot ductility of TWIP steels has not been clearly described.

Development of Nb-added TWIP steels requires understanding of the impact of $\mathrm{Nb}$ addition on castability, solidification microstructures, and high-temperature tensile properties of TWIP steels. The present work therefore aims at understanding the effect of $\mathrm{Nb}$ on solidification microstructures and high-temperature mechanical properties of $\mathrm{Fe}-17 \mathrm{Mn}-0.6 \mathrm{C}-1.5 \mathrm{Al}-\mathrm{xNb}$ TWIP steels with a systematic variation of $\mathrm{Nb}$ content. To correctly describe the solidification process of micro-alloyed steels, it is essential to understand the partitioning of solutes between dendritic regions and 
interdendritic regions and the formation behavior of precipitates. Phase-field models are useful for the simulation of microstructure evolution during solidification. ${ }^{[23-26]}$ Therefore, the present work combines thermodynamics-based phase-field modeling, thermo-mechanical simulation tests and in-depth microstructural characterization and reports on the effect of $\mathrm{Nb}$ on solidification microstructures and high-temperature mechanical properties.

\section{PHASE-FIELD SIMULATION}

Phase-field computations, using the Micress ${ }^{\circledR}$ phasefield modeling software coupled to the Thermo-Calc ${ }^{\circledR}$ equilibrium computational thermodynamics software, were conducted to provide information about the evolution of solidification microstructures, elemental distribution and precipitation of compounds in equilibrium and off-equilibrium conditions. The software Micress ${ }^{\circledR}$ is based on the phase-field concept for various multiphase systems including steels. ${ }^{[27]}$ The cast microstructures were obtained within an initial cell where spatial and temporal phase field, $\phi_{i}(\bar{x}, t)$, corresponded to $i$ phase $\left(\phi_{i}=1\right)$ and diffuse boundaries $\left(0<\phi_{i}<1\right)$. The following governing equation was solved at each time step using the coupled thermodynamic database:

Table I. Composition of the TWIP Steels Used in the Present Study

\begin{tabular}{lcccc}
\hline Steel & C Wt Pct & Mn Wt Pct & Al Wt Pct & Nb Wt Pct \\
\hline Reference & 0.59 & 16.3 & 1.29 & $\mathbf{0 . 0 0 0}$ \\
$25 \mathrm{Nb}$ & 0.61 & 16.7 & 1.45 & $\mathbf{0 . 0 2 5}$ \\
$50 \mathrm{Nb}$ & 0.61 & 16.9 & 1.52 & $\mathbf{0 . 0 4 8}$ \\
$100 \mathrm{Nb}$ & 0.59 & 16.3 & 1.48 & $\mathbf{0 . 0 8 8}$ \\
\hline
\end{tabular}

Bold values indicate the change of $\mathrm{Nb}$ chemical composition.

$$
\dot{\phi}(\bar{x}, t)=\mu\left[\sigma\left(\nabla^{2} \phi-\frac{(1-\phi)(1-2 \phi) \phi}{\eta^{2}}\right)+\frac{1}{\eta} \Delta G \phi(1-\phi)\right],
$$

where $\mu$ is the interfacial mobility; $\sigma$ is the interfacial energy; $\eta$ is the interfacial thickness, and $\Delta G$ is the thermodynamic driving force. ${ }^{[28-31]}$

Dendritic casting microstructures and precipitation behavior of the Fe-17Mn-0.6C-1.5Al-xNb steels were simulated by phase-field modeling. The initial cells were $400 \mu \mathrm{m} \times 600 \mu \mathrm{m}$ in size, and they were fully liquid phases containing a zero-radius austenitic seed at the center of the cells. The simulations were started at $1688 \mathrm{~K}\left(1415^{\circ} \mathrm{C}\right)$ using a cooling rate of $1.3 \mathrm{~K} \mathrm{~s}^{-1}$, a typical cooling rate in continuous casting processes. Phase and interface mobility data used for the phasefield computations were obtained via coupling of the Micress ${ }^{\circledR}$ software with the Thermo-Calc ${ }^{\circledR}$ TCFE 7 database. The cells used for calculations of $\mathrm{NbC}$ precipitation behavior were $10 \mu \mathrm{m} \times 5 \mu \mathrm{m}$ in size. The starting cells had two flat liquid/austenite interfaces.

\section{EXPERIMENTAL}

Four TWIP steels containing 0, 0.025, 0.05, and 0.1 wt pet $\mathrm{Nb}$ were prepared by vacuum induction melting. Hereafter, the TWIP steel containing $0,0.025$, 0.05 , and $0.1 \mathrm{wt}$ pct $\mathrm{Nb}$ is referred to as the reference, $25 \mathrm{Nb}, 50 \mathrm{Nb}$, and $100 \mathrm{Nb}$ steel, respectively. The chemical composition of the TWIP steels is listed in Table I. The experimental ingots had a dimension of $15 \mathrm{~cm} \times 15 \mathrm{~cm} \times 6 \mathrm{~cm}$.

As-cast microstructures were investigated by scanning electron microscopy (SEM), electron probe micro-analysis (EPMA). Samples for SEM and EPMA analysis were prepared by mechanical polishing, followed by electrolytic polishing. Electrolytic polishing was conducted in a mixture of 5 pct perchloric acid and 95 pct ethanol using a voltage range of 20 to $40 \mathrm{~V}$. SEM observations were conducted with a JEOL JEM-7100F

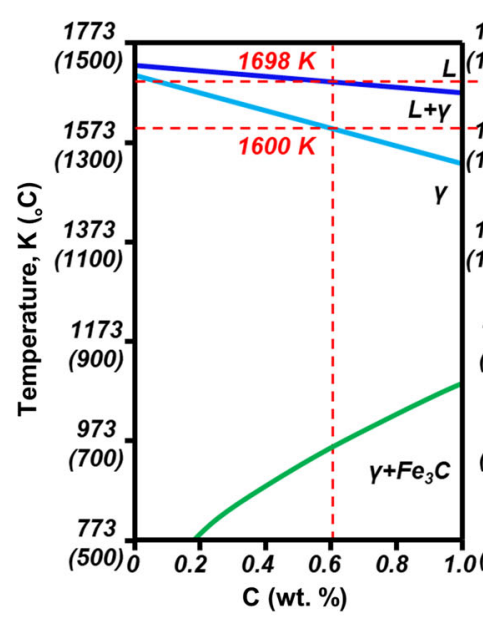

(a)

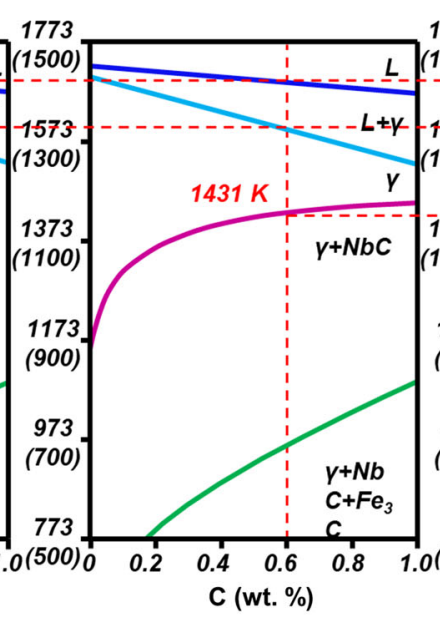

(b)

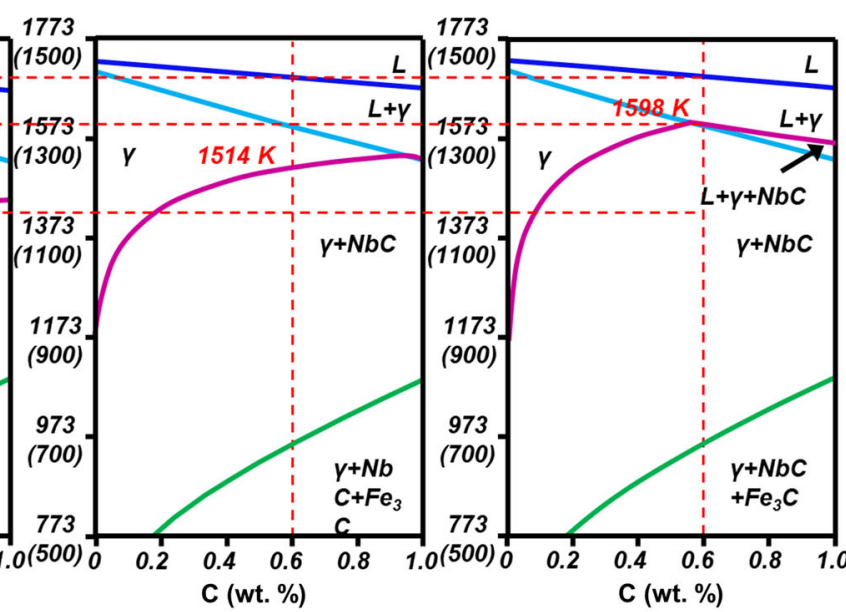

(c)

(d)

Fig. 1-Pseudo-binary equilibrium phase diagram of the (a) Nb-free reference steel, (b) $25 \mathrm{Nb}$ steel, (c) $50 \mathrm{Nb}$ steel, and (d) $100 \mathrm{Nb}$ steel. 


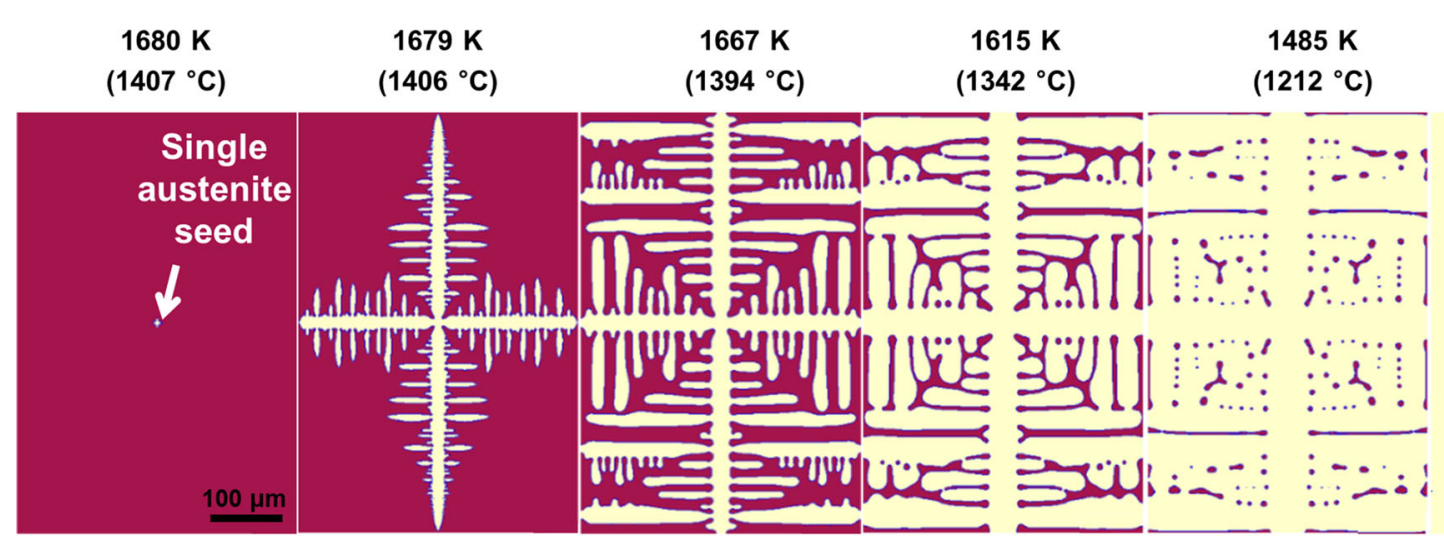

(a)

)

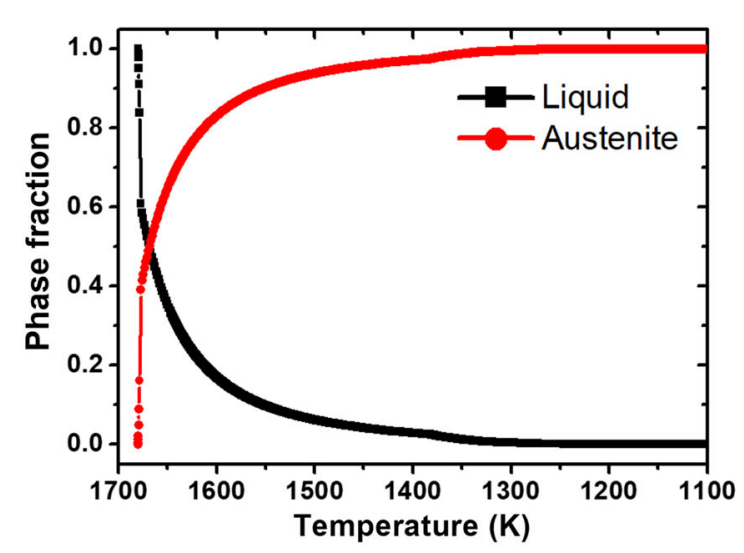

(b)

Fig. 2-Phase-field simulated (a) phase maps showing distribution of austenite and liquid phase during cooling and $(b)$ phase fraction of austenite and liquid during cooling for the $\mathrm{Nb}$-free reference steel.

SEM operating at $15 \mathrm{kV}$. Elemental analysis of precipitates was conducted by energy dispersive X-ray spectroscopy (EDS) in SEM. Elemental distribution in the as-cast materials was examined in a JEOL JXA-8100 EPMA operated at $15 \mathrm{kV}$ using a step size of $0.4 \mu \mathrm{m}$.

High-temperature tensile tests were conducted in a laboratory continuous casting and thermo-mechanical simulator. Cylindrical tensile specimens were machined from the cast materials along one of the long edges $(15 \mathrm{~cm})$ of the ingots, with $10 \mathrm{~mm}$ in diameter, $150 \mathrm{~mm}$ in length and with a gauge section of $6 \mathrm{~mm}$ in diameter and $7 \mathrm{~mm}$ in length. The specimens were heated to $1173 \mathrm{~K}, 1373 \mathrm{~K}$, and $1473 \mathrm{~K}\left(900{ }^{\circ} \mathrm{C}, 1100{ }^{\circ} \mathrm{C}\right.$, and $1200{ }^{\circ} \mathrm{C}$ ) with a heating rate of $10 \mathrm{~K} \mathrm{~s}^{-1}$, followed by isothermal holding for 200 seconds. Subsequently, the specimens were strained at a strain rate of $5.7 \times 10^{-3} \mathrm{~s}^{-1}$. The microstructures in gauge areas of the tensile specimens after high-temperature tensile tests were investigated by EPMA and transmission electron microscopy (TEM). TEM samples were prepared as 3-mm-diameter disks which were mechanically polished to a thickness less than $100 \mu \mathrm{m}$ and thinned by an electrolytic double jet technique at room temperature. A mixture of 5 pct perchloric acid and 95 pct ethanol was used as electrolyte. TEM observations were conducted in a JEOL JEM-2100F TEM operating at $200 \mathrm{kV}$.

\section{RESULTS}

\section{A. Phase-Field Simulation of Casting Microstructures of Fe-Mn-C-Al-xNb TWIP Steels}

Figure 1 shows equilibrium phase diagrams of the investigated TWIP steels, calculated by Thermo-Calc. Equilibrium solidification-start and solidification-finish temperature of the reference $\mathrm{Fe} 17 \mathrm{Mn} 0.6 \mathrm{C} 1.5 \mathrm{Al}$ steel is $1698 \mathrm{~K}$ and $1600 \mathrm{~K}\left(1425^{\circ} \mathrm{C}\right.$ and $\left.1327^{\circ} \mathrm{C}\right)$, respectively. $\mathrm{Nb}$ addition shows a negligible effect on these temperatures. At the constant $\mathrm{C}$ content of $0.6 \mathrm{wt}$ pct, equilibrium $\mathrm{NbC}$ precipitation start temperature increases considerably by $\mathrm{Nb}$ addition, i.e., from $1431 \mathrm{~K}\left(1158^{\circ} \mathrm{C}\right)$ for the $25 \mathrm{Nb}$ steel to $1598 \mathrm{~K}$ $\left(1325^{\circ} \mathrm{C}\right)$ for the $100 \mathrm{Nb}$ steel.

Figure 2 shows Micress-simulated solidification behavior of the reference steel below the equilibrium solidification-start temperature. Figure 2(a) shows phase distribution of austenite and liquid phase during cooling. The austenite seed develops into austenitic dendrites and the fraction of austenite increases during cooling. At $1485 \mathrm{~K}\left(1212^{\circ} \mathrm{C}\right)$, the percentage of austenite is about 90 pct. The phase map at $1093 \mathrm{~K}\left(820^{\circ} \mathrm{C}\right)$ in Figure 2(a) shows that complete solidification is still not achieved at this temperature. Equilibrium solidification-finish temperature is $1600 \mathrm{~K}\left(1327^{\circ} \mathrm{C}\right)$ for the 


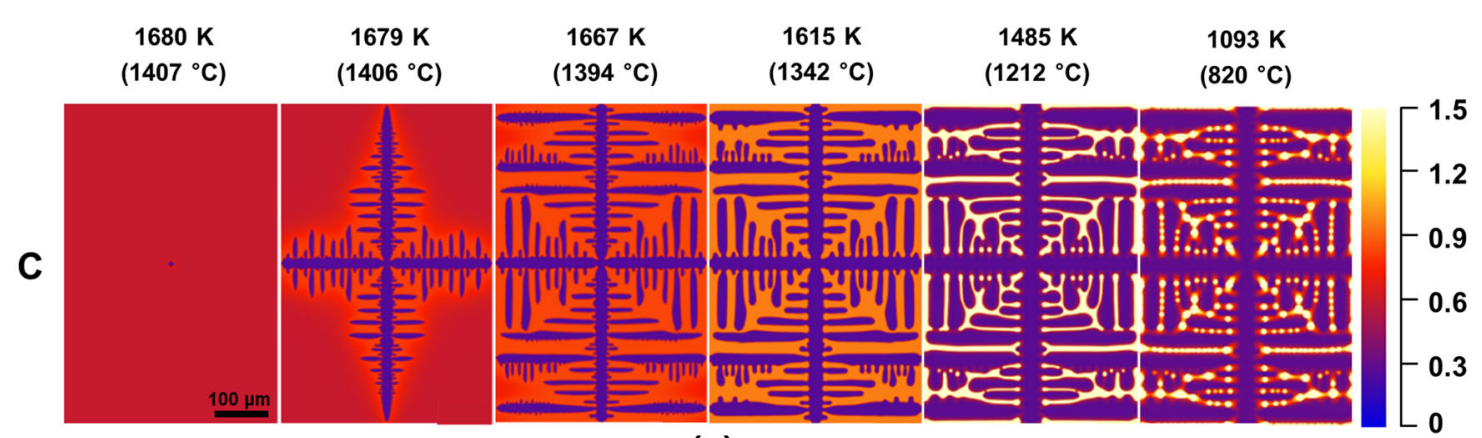

(a)

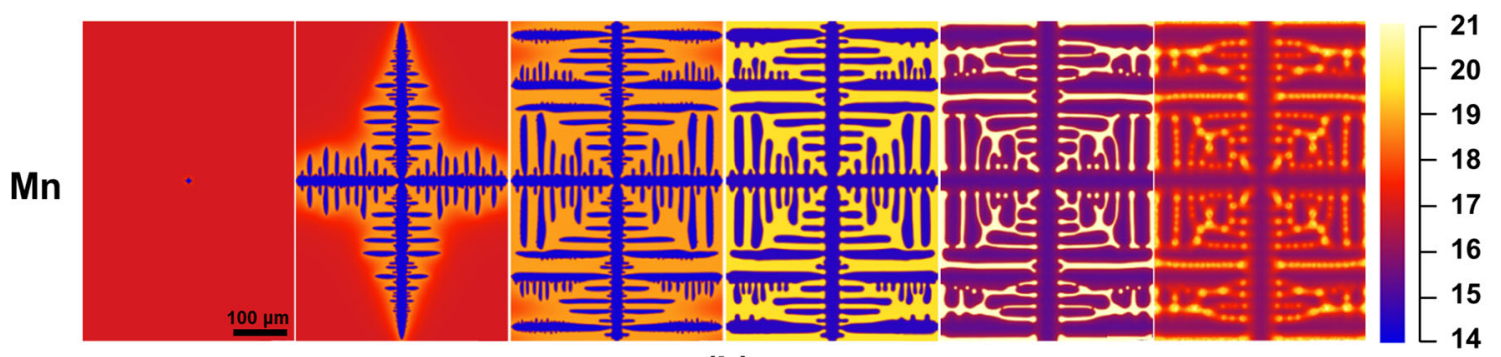

(b)

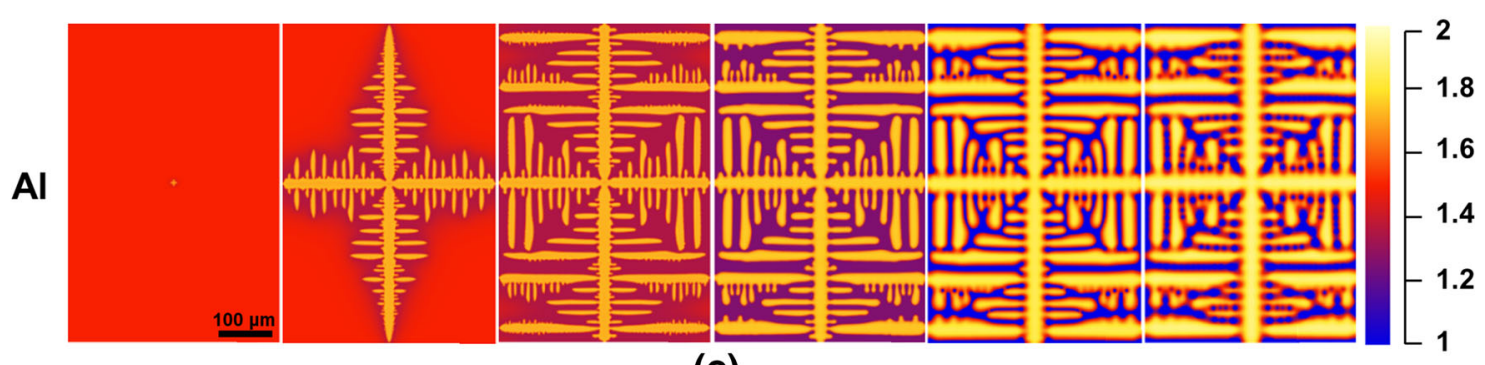

(c)

Fig. 3-Phase-field simulated elemental distribution maps of (a) C, (b) Mn, and (c) Al for the Nb-free reference steel.

reference steel (Figure 1(a)). In contrast, the Micress simulation, which considers solidification kinetics, predicts that 99 pet of liquid phase is solidified at $1333 \mathrm{~K}$ $\left(1060{ }^{\circ} \mathrm{C}\right.$ ) for a cooling rate of $1.3 \mathrm{~K} \mathrm{~s}^{-1}$ (Figure 2(b)). Phase-field simulation predicts a much wider solidification temperature range as compared to equilibrium Thermo-Calc calculations. Below $1615 \mathrm{~K} \quad\left(1342{ }^{\circ} \mathrm{C}\right)$, isolated islands of liquid phase are formed in the inter-dendritic regions. These may become potential sites for the formation of micro-porosities, which reduces hot ductility of steel. ${ }^{[10]}$

Figure 3 shows the Micress-simulated evolution of elemental distribution of $\mathrm{C}, \mathrm{Mn}$, and $\mathrm{Al}$ in the reference steel during cooling. Figures 3(a) and (b) show that $\mathrm{C}$ and $\mathrm{Mn}$ are enriched in the liquid inter-dendritic regions. In contrast, Figure $3(\mathrm{c})$ shows that $\mathrm{Al}$ is enriched in the austenite dendritic regions.

Figure 4(a) shows the Micress-simulated phase map at $1576 \mathrm{~K}\left(1303{ }^{\circ} \mathrm{C}\right)$ for the reference steel, which consists of liquid and austenite. Figures 4(b) through (d) show temperature-dependent concentration plots of $\mathrm{Mn}, \mathrm{C}$, and $\mathrm{Al}$ along the black line drawn across the dendrite/liquid boundaries in Figure 4(a). Figure 4(b) shows that width of the dendrite increases with decreasing temperature due to growth of the dendrite. At $1679 \mathrm{~K}\left(1406{ }^{\circ} \mathrm{C}\right)$, the dendrite has Mn concentration of approximately $14 \mathrm{wt}$ pct while the inter-dendritic liquid has Mn concentration of about 19 wt pet. With decreasing temperature, average $\mathrm{Mn}$ concentration in both regions increases and degree of $\mathrm{Mn}$ partitioning also increases. For example, at $1485 \mathrm{~K}$ $\left(1212^{\circ} \mathrm{C}\right)$, the dendrite has $\mathrm{Mn}$ concentration of approximately $16 \mathrm{wt}$ pct while the inter-dendritic region has $\mathrm{Mn}$ concentration of approximately $23 \mathrm{wt}$ pct. At $1093 \mathrm{~K}\left(820{ }^{\circ} \mathrm{C}\right)$, however, average Mn concentration of the inter-dendritic regions is lower than that at $1485 \mathrm{~K}\left(1212^{\circ} \mathrm{C}\right)$. The Mn concentration of the dendrite is higher than that at $1485 \mathrm{~K}\left(1212{ }^{\circ} \mathrm{C}\right)$. The decreased $\mathrm{Mn}$ concentration in the inter-dendritic regions at $1093 \mathrm{~K}\left(820{ }^{\circ} \mathrm{C}\right)$ is due to merge of the dendrite with the neighboring dendrite. At $1093 \mathrm{~K}$ $\left(820{ }^{\circ} \mathrm{C}\right)$, the $\mathrm{Mn}$ concentration in the dendritic region ranges from 16 to $17 \mathrm{wt}$ pct while that in the inter-dendritic regions ranges from 18 to $19 \mathrm{wt}$ pct. In addition, difference in $\mathrm{Mn}$ concentration between the dendritic region and inter-dendritic regions at $1093 \mathrm{~K}\left(820^{\circ} \mathrm{C}\right)$ is reduced as compared to the situation at $1485 \mathrm{~K}\left(1212{ }^{\circ} \mathrm{C}\right)$. 


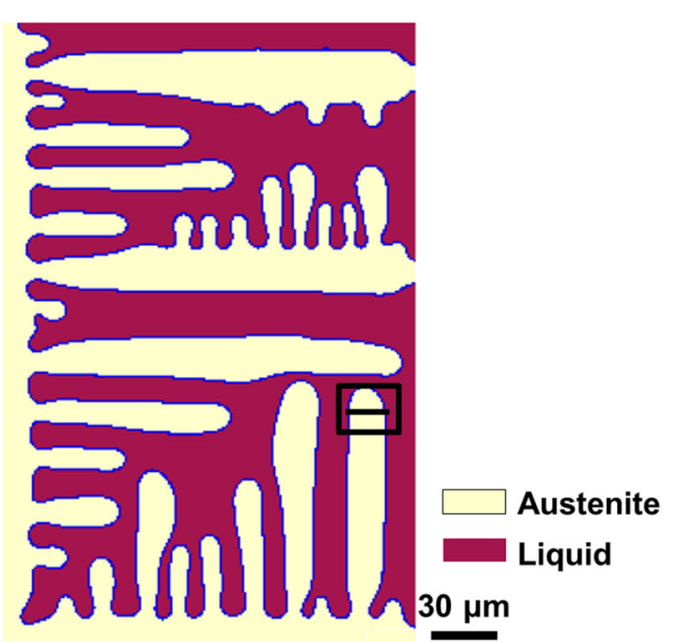

(a)

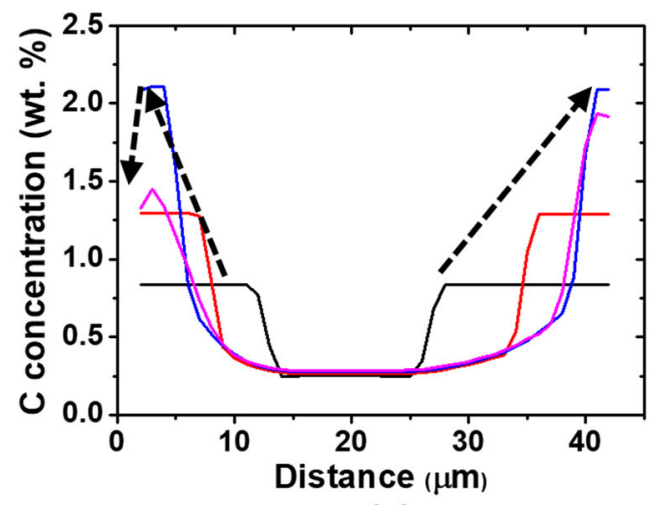

(c)

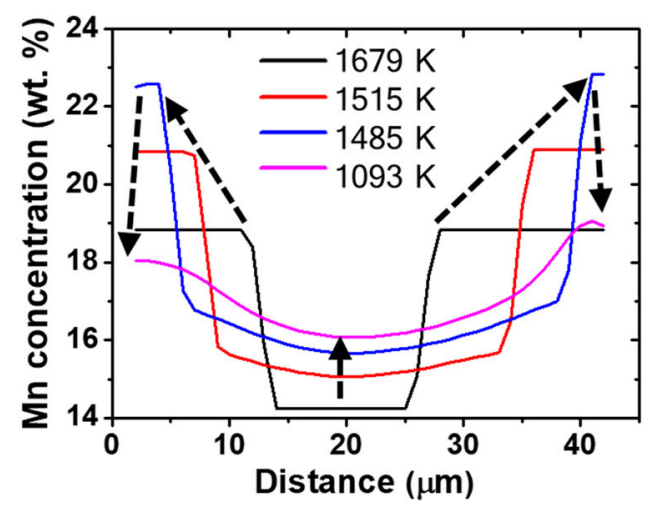

(b)

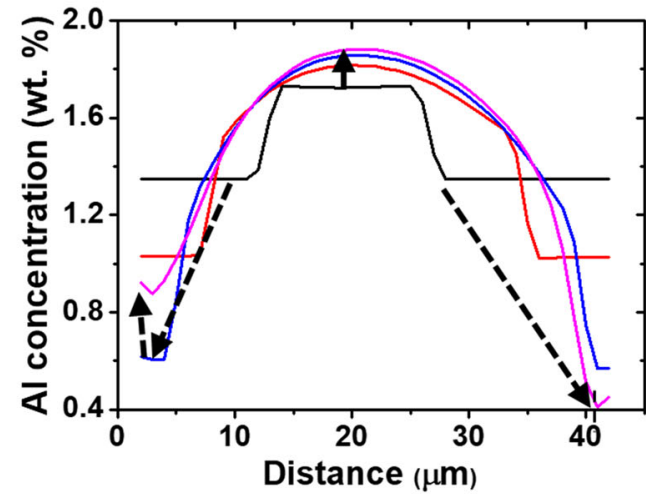

(d)

Fig. 4-Phase-field simulated (a) phase map at $1576 \mathrm{~K}\left(1303{ }^{\circ} \mathrm{C}\right)$ for the reference steel, which consists of liquid and austenite. Temperature-dependent concentration plots of $(b) \mathrm{Mn},(c) \mathrm{C}$, and $(d) \mathrm{Al}$ along the black line drawn across the dendrite/liquid boundaries in (a).

Figure 4(c) shows that $\mathrm{C}$ is enriched in the inter-dendritic liquid phase. The $\mathrm{C}$ concentration in the dendrite remains almost unchanged with decreasing temperature. The dendrite has $\mathrm{C}$ concentration of approximately 0.3 wt pct. With decreasing temperature, average $\mathrm{C}$ concentration of the liquid inter-dendritic regions increases and then decreases. The $\mathrm{C}$ concentration in the inter-dendritic regions is higher than $2 \mathrm{wt}$ pct at 1485 $\mathrm{K}\left(1212{ }^{\circ} \mathrm{C}\right)$, and ranges from 1.3 to $2 \mathrm{wt}$ pct at $1093 \mathrm{~K}$ $\left(820^{\circ} \mathrm{C}\right)$.

In contrast to distribution of $\mathrm{Mn}$ and $\mathrm{C}, \mathrm{Al}$ is enriched in the solidified dendrite as shown in Figure 4(d). The average Al concentration in the dendrite gradually increases with decreasing temperature from approximately $1.7 \mathrm{wt}$ pct at $1679 \mathrm{~K}\left(1406^{\circ} \mathrm{C}\right)$ to approximately $1.9 \mathrm{wt}$ pet at $1093 \mathrm{~K}\left(820{ }^{\circ} \mathrm{C}\right)$. The $\mathrm{Al}$ concentration in the inter-dendritic regions is approximately $1.4 \mathrm{wt}$ pct at $1679 \mathrm{~K}\left(1406^{\circ} \mathrm{C}\right)$, and it ranges from 0.4 to $0.9 \mathrm{wt}$ pet at $1093 \mathrm{~K}\left(820^{\circ} \mathrm{C}\right)$.

Figure 5 shows the Micress-simulated solidification behavior of the $100 \mathrm{Nb}$ steel from the equilibrium solidification-start temperature to the $\mathrm{NbC}$ formation temperature. $\mathrm{Nb}$ is enriched in inter-dendritic liquid phase (Figure 5(a)). Figure 5(b) shows a
Micress-simulated $\mathrm{Nb}$ distribution map at $1641 \mathrm{~K}$ $\left(1368^{\circ} \mathrm{C}\right)$. Figure 5(c) shows temperature-dependent concentration plots of $\mathrm{Nb}$ along the black line drawn across the dendrite/liquid boundaries in Figure 5(b). The $\mathrm{Nb}$ concentration in the dendrite remains almost unchanged with decreasing temperature. The dendrite has $\mathrm{Nb}$ concentration of approximately $0.03 \mathrm{wt}$ pct. Average $\mathrm{Nb}$ concentration of the inter-dendritic regions increases with decreasing temperature. The $\mathrm{Nb}$ concentration in the inter-dendritic regions is approximately 0.15 wt pet at $1677 \mathrm{~K}\left(1404{ }^{\circ} \mathrm{C}\right)$ and 0.23 wt pet at $1641 \mathrm{~K}\left(1368^{\circ} \mathrm{C}\right)$. Considering that both $\mathrm{C}$ and $\mathrm{Nb}$ are enriched in the inter-dendritic region, $\mathrm{NbC}$ precipitation is expected to occur in this region.

$\mathrm{NbC}$ precipitation behavior for the Nb-added TWIP steels was simulated using a starting cell with two flat liquid/austenite interfaces. Figure 6(a) shows the simulated phase maps and distribution of $\mathrm{NbC}$ precipitates at $1379 \mathrm{~K}\left(1106{ }^{\circ} \mathrm{C}\right)$. The phase maps show thin inter-dendritic zones composed of the solid phase and the remained liquid phase. The distribution maps of $\mathrm{NbC}$ precipitates show preferential presence of the precipitates near inter-dendritic boundaries. Figure 6(b) shows quantitative information on $\mathrm{NbC}$ 


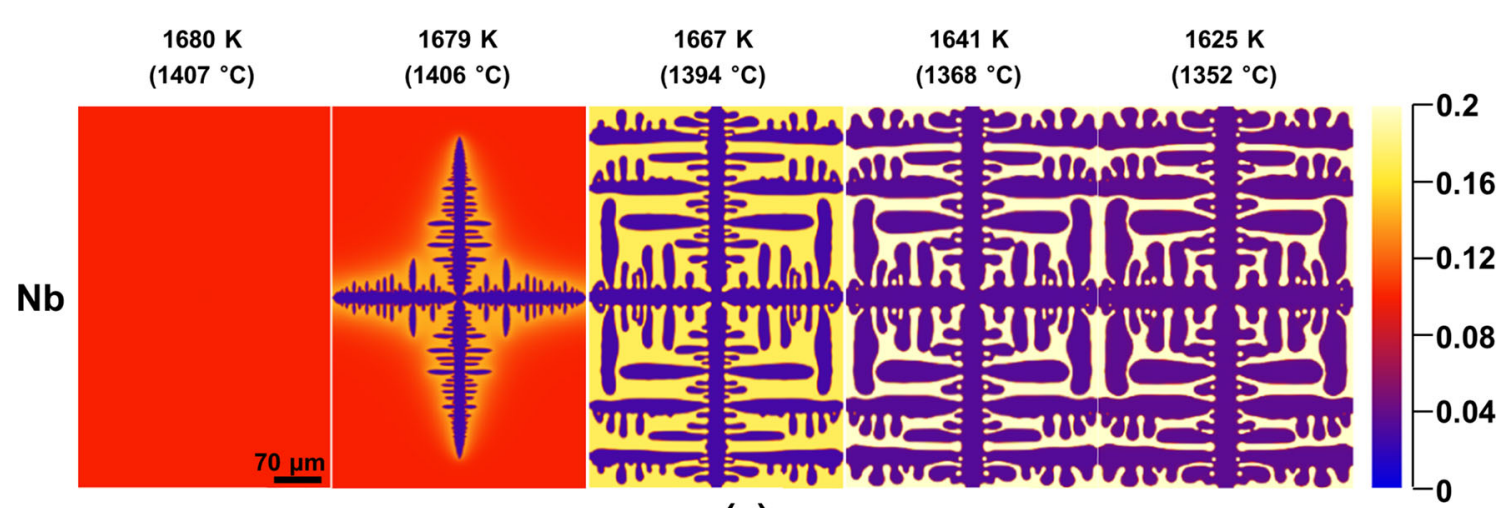

(a)

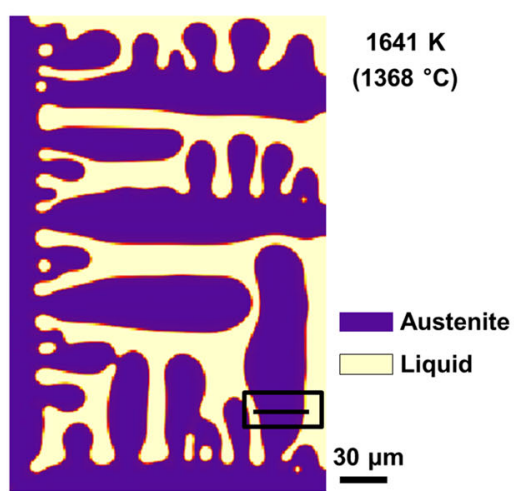

(b)

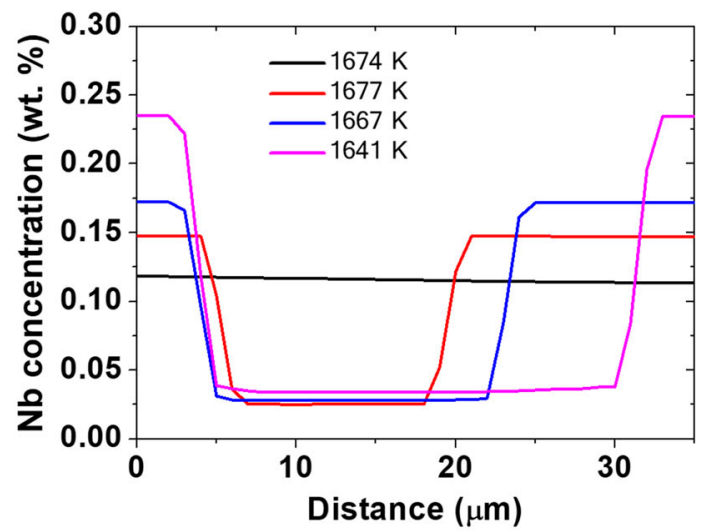

(c)

Fig. 5-Phase-field simulated (a) $\mathrm{Nb}$ distribution maps for the $100 \mathrm{Nb}$ steel, $(b) \mathrm{Nb}$ distribution map at $1641 \mathrm{~K}\left(1368{ }^{\circ} \mathrm{C}\right)$, and $(c)$ temperature-dependent $\mathrm{Nb}$ concentration along the black line drawn across the dendrite/liquid boundaries in (b).

precipitation, obtained by Micress-simulation. Average radius of $\mathrm{NbC}$ precipitates ranges from 15 to $35 \mathrm{~nm}$, and it increases with increasing $\mathrm{Nb}$ concentration. Volume percentage of $\mathrm{NbC}$ precipitates also increases with increasing $\mathrm{Nb}$ concentration. It is approximately 0.07 pct for the $100 \mathrm{Nb}$ steel. The $\mathrm{NbC}$ precipitation start temperature increases with increasing $\mathrm{Nb}$ concentration. The precipitation start temperature obtained by the Micress simulation is about $100 \mathrm{~K}$ lower than the equilibrium precipitation start temperature predicted by the Thermo-Calc calculations shown in Figure 1.

\section{B. Characterization of Casting Microstructures of Fe-Mn-C-Al-xNb TWIP Steels}

Figure 7 presents EPMA elemental distribution maps of $\mathrm{Mn}, \mathrm{C}$, and $\mathrm{Al}$ for the as-cast reference steel. Figure 7(b) shows inhomogeneous $\mathrm{Mn}$ distribution. While the dendrites have low Mn concentration, the inter-dendritic regions are Mn-enriched. This is in agreement with the Micress simulation results (Figure 3). The C distribution map of Figure 7(c) shows the presence of coarse cementite precipitates indicated by black circles. Smaller C-rich particles are also present in the microstructure. These are most likely fine cementite precipitates. Figure 7(d) shows particles indicated by red circles, and the particles are identified as AlN precipitates.

Figure 8 compares the concentration of $\mathrm{Mn}, \mathrm{C}$, and Al along the black-dotted line in Figure 7 with the Micress-simulated compositional profiles at $1093 \mathrm{~K}$ $\left(820^{\circ} \mathrm{C}\right)$. The concentration is plotted with respect to distance of the black-dotted line in Figure 7 for EPMA analysis and with respect to the black line in Figure 4(a) for Micress simulation. The Mn concentration from EPMA analysis shows similar distribution with the Micress-simulated Mn concentration, showing higher $\mathrm{Mn}$ concentration in the inter-dendritic region. In contrast, Figures 7(b) and (c) show that the experimentally determined distribution of $\mathrm{C}$ and $\mathrm{Al}$ does not show clear micro-segregation in either the inter-dendritic or the dendritic region. A scale of local compositional variations of $\mathrm{C}$ and $\mathrm{Al}$ is smaller than the micro-segregation distance between dendrites. The experimentally determined distribution of $\mathrm{C}$ and $\mathrm{Al}$ is not consistent with the Micress-simulation results. Absence of micro-segregation of $\mathrm{C}$ and $\mathrm{Al}$ in EPMA analysis is most likely due to formation of cementite and AlN precipitates.

Figure 9 presents EPMA elemental distribution maps of $\mathrm{Mn}, \mathrm{C}$, and $\mathrm{Nb}$ for the $100 \mathrm{Nb}$ steel. Figure 9(b) shows that the microstructure of $100 \mathrm{Nb}$ steel shows 


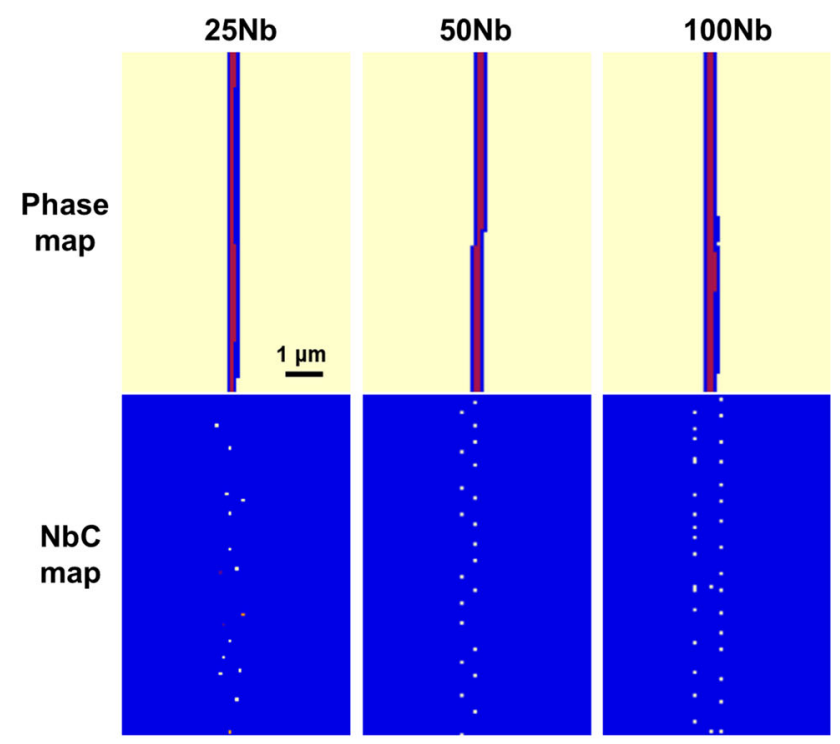

(a)
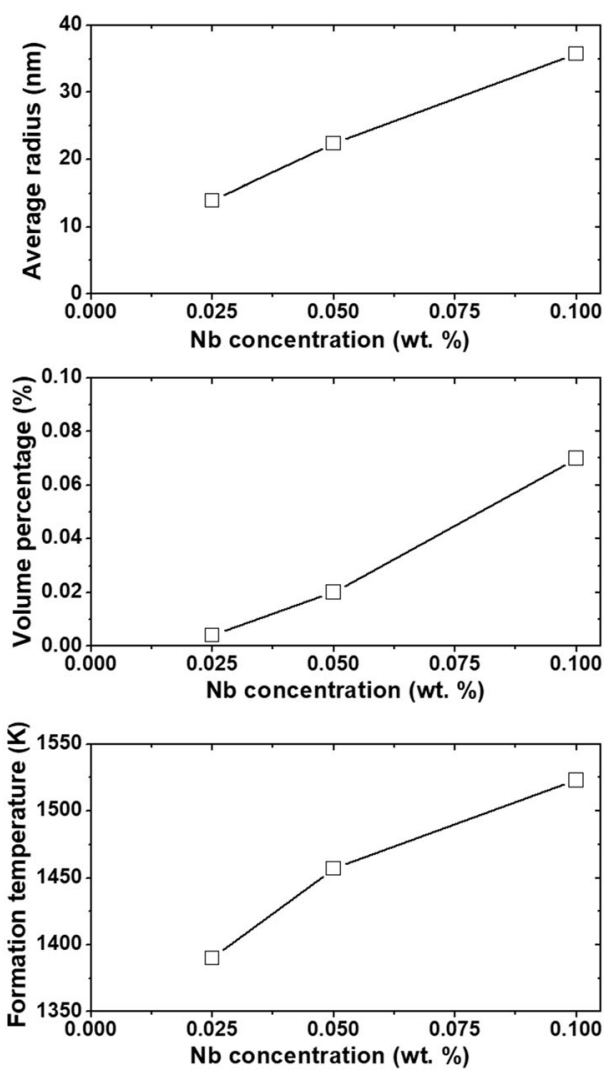

(b)

Fig. 6-(a) Phase-field simulated phase maps and distribution of $\mathrm{NbC}$ precipitates for the $\mathrm{Nb}$-added steels at $1379 \mathrm{~K}\left(1106{ }^{\circ} \mathrm{C}\right) .(b)$ $\mathrm{Nb}$ concentration dependence of the precipitation start temperature, the volume percentage, and the average radius of the $\mathrm{NbC}$ precipitates.

inhomogeneous distribution of Mn. The C (Figure 9(c)) and $\mathrm{Nb}$ (Figure 9(d)) distribution maps show presence of $\mathrm{NbC}$ precipitates, preferentially located at interdendritic boundaries. The preferential presence of $\mathrm{NbC}$ precipitates at interdendritic boundaries is consistent with the Micress-simulation results in Figure 6.

Figure 10 shows SEM micrographs and EDS spectra of the identified precipitates in the reference steel and the $100 \mathrm{Nb}$ steel. AlN precipitates and $\mathrm{MgO}$ inclusions are present in all the investigated steels. $\mathrm{MgO}$ inclusions are often associated with AlN precipitates as shown in Figure 10(b). Figure 10(d) shows the SEM micrograph and the corresponding EDS spectrum for a $\mathrm{NbC}$ precipitate in the $100 \mathrm{Nb}$ steel. The EPMA analysis for the $100 \mathrm{Nb}$ steel in Figure 9 shows that $\mathrm{NbC}$ precipitates are more frequently observed compared to AlN precipitates.

\section{High-Temperature Mechanical Properties and Deformation Microstructures of Fe-Mn-C-Al-xNb TWIP Steels}

High-temperature tensile tests were conducted at $1173 \mathrm{~K}, 1373 \mathrm{~K}$, and $1474 \mathrm{~K}\left(900{ }^{\circ} \mathrm{C}, 1100{ }^{\circ} \mathrm{C}\right.$, and $1200{ }^{\circ} \mathrm{C}$ ) for all the investigated TWIP steels. Figure 11(a) shows details of test procedures. Figures 11(b) through (d) provide stress-strain curves of the investigated TWIP steels. Peak stresses decrease with increasing deformation temperature for all the investigated steels. The stress-strain curves at $1173 \mathrm{~K}$ $\left(900{ }^{\circ} \mathrm{C}\right)$ in Figure 11(b) show that strength of the $\mathrm{Nb}$-added steels is higher than that of the reference steel. The $100 \mathrm{Nb}$ steel shows the highest peak stress while the reference steel shows the lowest peak stress. Fracture strain of the reference steel is slightly larger than that of the $\mathrm{Nb}$-added steels. The peak stresses at $1173 \mathrm{~K}$ $\left(900{ }^{\circ} \mathrm{C}\right.$ ) range from 80 to $110 \mathrm{MPa}$. The stress-strain curves at $1373 \mathrm{~K}\left(1100{ }^{\circ} \mathrm{C}\right)$ in Figure $11(\mathrm{c})$ shows that the $50 \mathrm{Nb}$ steel has the highest peak stress, and the $100 \mathrm{Nb}$ steel has the largest fracture strain. The peak stresses at $1373 \mathrm{~K}\left(1100^{\circ} \mathrm{C}\right)$ range from 40 to $60 \mathrm{MPa}$. Figure 11(d) shows the stress-strain curves at $1473 \mathrm{~K}$ $\left(1200{ }^{\circ} \mathrm{C}\right)$. The peak stresses for all the investigated TWIP steels are similar at $1473 \mathrm{~K}\left(1200^{\circ} \mathrm{C}\right)$. The $\mathrm{Nb}$-added steels show larger fracture strain than the reference steel. The peak stresses at $1473 \mathrm{~K}\left(1200{ }^{\circ} \mathrm{C}\right)$ are approximately $30 \mathrm{MPa}$. Mejía et al..$^{[14]}$ investigated effect of $\mathrm{Nb}$ and $\mathrm{Mo}$ on the high-temperature mechanical properties of an as-cast Fe-21Mn-1.3Al-1.5Si-0.5C (wt pct) TWIP steel produced by ingot casting in a sand mold. They reported that the peak stress of the $\mathrm{Nb}$-added TWIP steel at $1173 \mathrm{~K}\left(900{ }^{\circ} \mathrm{C}\right)$ was higher than that of their reference Nb-free TWIP steel. They also reported similar peak stresses for both the reference steel and the $\mathrm{Nb}$-added steel at $1373 \mathrm{~K}\left(1100{ }^{\circ} \mathrm{C}\right)$. Lan et al. ${ }^{[16]}$ investigated high-temperature mechanical properties of an as-cast Fe-22Mn-0.7C (wt pct) TWIP steel in the range of $973 \mathrm{~K}$ to $1573 \mathrm{~K}\left(700{ }^{\circ} \mathrm{C}\right.$ to $\left.1300{ }^{\circ} \mathrm{C}\right)$. They reported that the peak stress decreases with increasing deformation temperature. These results ${ }^{[14,16]}$ are in agreement with those of the present work.

Figure 12(a) presents stress-strain curves of the reference steel at different deformation temperatures. The strength decreases with increasing deformation temperature. The area under the stress-strain curve, i.e., the energy absorption capacity, is $3805 \mathrm{MPa}$ pet for $1173 \mathrm{~K}$ 


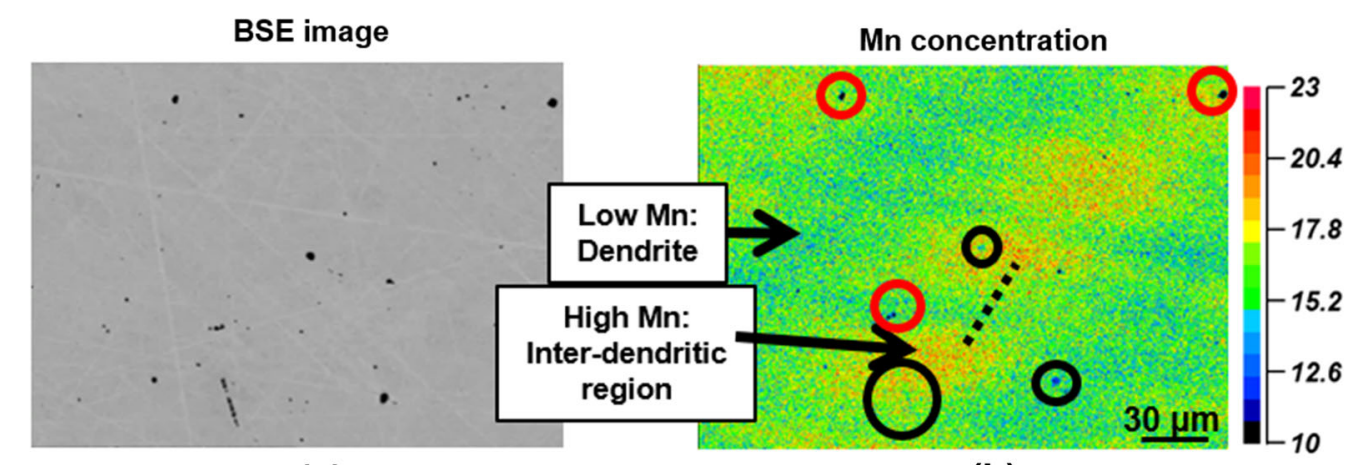

(a)

(b)

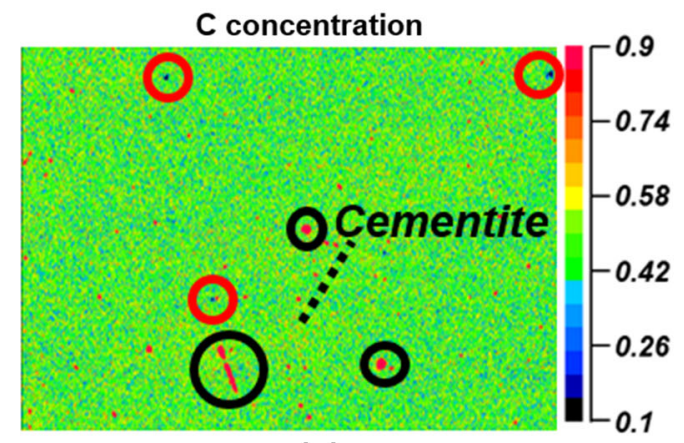

(c)

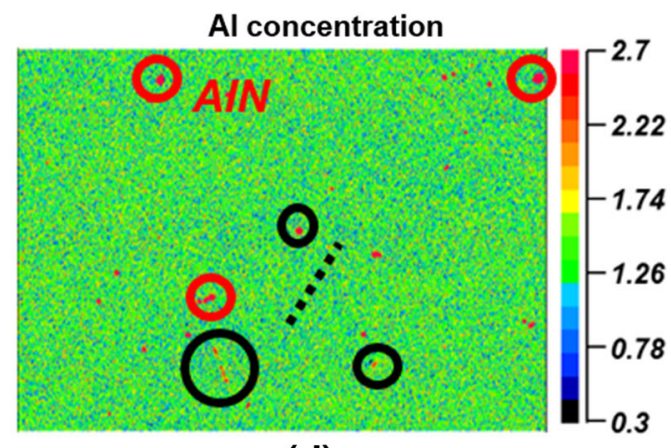

(d)

Fig. 7-(a) SEM backscattered electron (BSE) image and EPMA elemental distribution maps showing (b) Mn, (c) C and (d) Al concentration in the as-cast reference steel.

$\left(900{ }^{\circ} \mathrm{C}\right), 1514 \mathrm{MPa}$ pet for $1373 \mathrm{~K}\left(1100^{\circ} \mathrm{C}\right)$ and $1922 \mathrm{MPa}$ pct for $1473 \mathrm{~K}\left(1200^{\circ} \mathrm{C}\right)$. Figure 12 (b) shows the peak stress and the reduction of area (RA) with respect to deformation temperatures. The peak stress decreases continuously from $90 \mathrm{MPa}$ at $1173 \mathrm{~K}$ $\left(900{ }^{\circ} \mathrm{C}\right)$ to $28 \mathrm{MPa}$ at $1473 \mathrm{~K}\left(1200{ }^{\circ} \mathrm{C}\right)$ while the RA increases from $48 \mathrm{pct}$ at $1173 \mathrm{~K}\left(900^{\circ} \mathrm{C}\right)$ to 55 pct at $1373 \mathrm{~K}\left(1100{ }^{\circ} \mathrm{C}\right)$. The RA then slightly decreases to 54 pet at $1473 \mathrm{~K}\left(1200{ }^{\circ} \mathrm{C}\right)$. Lan et al. ${ }^{[16]}$ reported three brittle zones for an as-cast Fe-22Mn-0.7C (wt pct) TWIP steel. The first brittle zone was observed at temperatures above $1473 \mathrm{~K}\left(1200{ }^{\circ} \mathrm{C}\right)$. In this zone, RA of the TWIP steel decreased with increasing deformation temperature. The second brittle zone was observed from $1473 \mathrm{~K}$ to $1173 \mathrm{~K}\left(1200{ }^{\circ} \mathrm{C}\right.$ to $\left.900{ }^{\circ} \mathrm{C}\right)$ while the third second brittle zone was observed from $1223 \mathrm{~K}$ to $1073 \mathrm{~K}\left(950{ }^{\circ} \mathrm{C}\right.$ to $\left.800{ }^{\circ} \mathrm{C}\right)$. The third brittle zone showed lower hot ductility than the second brittle zone. The RA values of the $\mathrm{Nb}$-free reference steel in the present work are higher than those reported by Lan et $a l^{[16]}$ This could be due to the fact that the reference steel in the present work shows lower Mn concentration of 17 wt pct compared to the material investigated by Lan et al., ${ }^{[16]}$ since reduced $\mathrm{Mn}$ concentration results in an increase in hot ductility. ${ }^{[10,17]}$

Figure 13 shows EPMA elemental distribution maps of $\mathrm{Fe}, \mathrm{Mn}$, and $\mathrm{C}$ for the reference steel after deformation at different temperatures. The inhomogeneous distribution of $\mathrm{Mn}$ observed in the as-cast microstructure (Figure 7(a)) is still present after high-temperature tensile deformation, i.e., dendritic structures show low
Mn concentration while inter-dendritic regions show high Mn concentration. The AlN precipitates indicated by red circles are mostly present at interdendritic boundaries in the tested samples for all the deformation temperatures, and they are rarely present in the dendritic regions. Cavities and cracks are present in the tested samples for all the deformation temperatures. These defects indicated by black circles are primarily present in the Mn-rich inter-dendritic regions.

Figure 14(a) presents stress-strain curves of the $100 \mathrm{Nb}$ steel at different deformation temperatures. The strength decreases with increasing deformation temperature. The area under the stress-strain curve, i.e., the energy absorption capacity, is $4815 \mathrm{MPa}$ pct for $1173 \mathrm{~K}$ $\left(900^{\circ} \mathrm{C}\right), 2553 \mathrm{MPa}$ pet for $1373 \mathrm{~K}\left(1100{ }^{\circ} \mathrm{C}\right)$ and $1745 \mathrm{MPa}$ pct for $1473 \mathrm{~K}\left(1200^{\circ} \mathrm{C}\right)$. Figure $14(\mathrm{~b})$ shows temperature dependence of the peak stress and the RA. The peak stress decreases continuously from $110 \mathrm{MPa}$ at $1173 \mathrm{~K}\left(900{ }^{\circ} \mathrm{C}\right)$ to $33 \mathrm{MPa}$ at $1473 \mathrm{~K}\left(1200^{\circ} \mathrm{C}\right)$. The RA increases considerably from 24 pct at $1173 \mathrm{~K}$ $\left(900{ }^{\circ} \mathrm{C}\right)$ to 79 pet at $1473 \mathrm{~K}\left(1200{ }^{\circ} \mathrm{C}\right)$. The increase of RA from $1173 \mathrm{~K}\left(900{ }^{\circ} \mathrm{C}\right)$ to $1473 \mathrm{~K}\left(1200{ }^{\circ} \mathrm{C}\right)$ was also reported in a Fe-18Mn-0.6C-0.02Nb (wt pct) TWIP steel. ${ }^{[1]}$

Figure 15 shows EPMA elemental distribution maps of $\mathrm{Fe}, \mathrm{Mn}, \mathrm{Al}$, and $\mathrm{C}$ for the $100 \mathrm{Nb}$ steel after deformation at different temperatures. The materials show inhomogeneous distribution of Mn, similarly with the case of the reference steel. The AlN precipitates indicated by red circles are present in the steel after deformation at $1173 \mathrm{~K}, 1373 \mathrm{~K}$, and $1473 \mathrm{~K}\left(900{ }^{\circ} \mathrm{C}\right.$, 


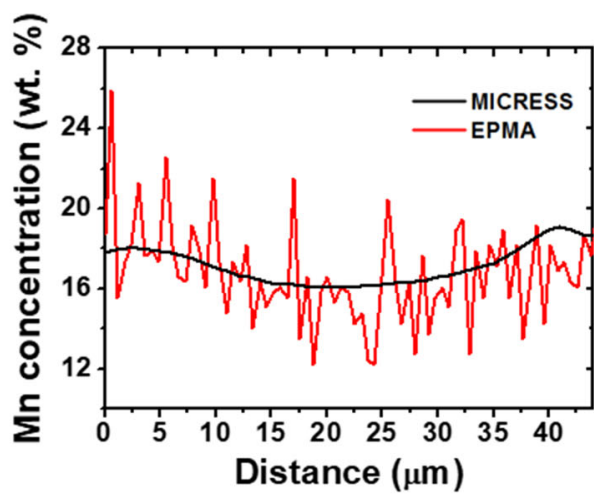

(a)

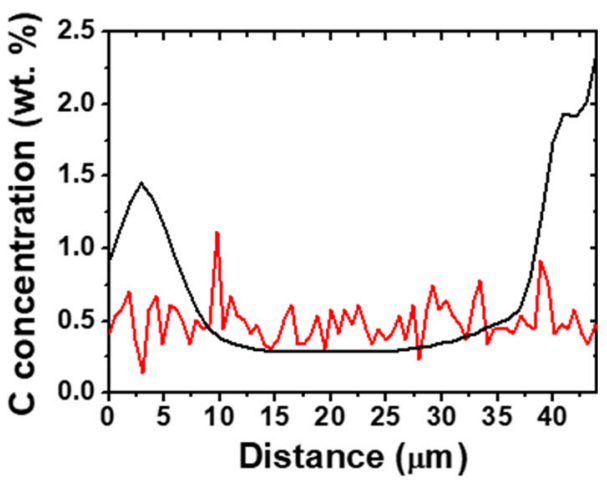

(b)

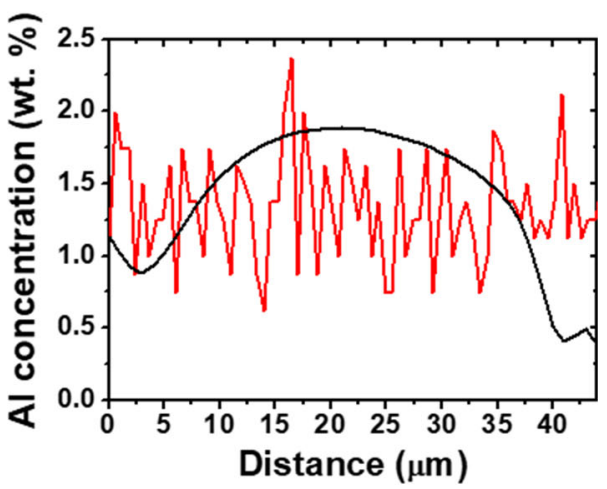

(c)

Fig. 8 - Comparison of concentration of $(a) \mathrm{Mn},(b) \mathrm{C}$, and $(c) \mathrm{Al}$ along the black-dotted line in Fig. 7 with the Micress-simulated compositional profiles at $1093 \mathrm{~K}\left(820^{\circ} \mathrm{C}\right)$. The concentration is plotted with respect to the distance of the black-dotted line in Fig. 7 for EPMA analysis and the black line in Fig. 4(a) for Micress simulation.

$1100{ }^{\circ} \mathrm{C}$, and $1200{ }^{\circ} \mathrm{C}$ ). $\mathrm{NbC}$ precipitates indicated by violet circles are mostly present at interdendritic boundaries. Cavities and cracks are present in the tested samples for all the deformation temperatures. These defects, indicated by black circles in Figure 15, are mostly present in the Mn-rich inter-dendritic regions.

Figure 16 summarizes deformation temperature dependence of RA for the investigated TWIP steels. Hot ductility decreases with increasing $\mathrm{Nb}$ concentration for the tests at $1173 \mathrm{~K}\left(900{ }^{\circ} \mathrm{C}\right)$. In contrast, hot ductility of the Nb-added steels is higher than that of the $\mathrm{Nb}$-free reference steel for the tests at $1373 \mathrm{~K}\left(1100{ }^{\circ} \mathrm{C}\right)$ and $1473 \mathrm{~K}\left(1200{ }^{\circ} \mathrm{C}\right)$. The observed different $\mathrm{Nb}$ effects on hot ductility of the investigated steels, depending on deformation temperatures, will be discussed in Section V.

\section{DISCUSSION}

Partitioning of alloying elements between the liquid phase and growing solid dendrites during solidification results in micro-segregation in solidified microstructures. ${ }^{[32]}$ Phase-field simulations showed that $\mathrm{Mn}, \mathrm{Nb}$, and $\mathrm{C}$ are enriched in inter-dendritic regions while $\mathrm{Al}$ is enriched in dendritic regions during solidification of the investigated TWIP steels. Enrichment of $\mathrm{C}$ and $\mathrm{Mn}$ in the inter-dendritic liquid phase (Figures 3(a), (b)) is consistent with previous works. ${ }^{[32,33]} \mathrm{Al}$ is known to have a small tendency to segregate to the solid phase, i.e., either in $\delta$-ferrite or austenite, during solidification of carbon steels. ${ }^{[33,34]}$ Ennis et al. ${ }^{[35]}$ however reported enrichment of $\mathrm{Al}$ in dendritic structures in an as-cast steel. Their observations are consistent with the Micress simulation in the present work (Figure 3(c)). Enrichment of $\mathrm{Nb}$ in the inter-dendritic liquid phase (Figure 5(a)) is also consistent with previous works that reported high tendency for $\mathrm{Nb}$ to segregate to the inter-dendritic liquid phase. ${ }^{[33,34]}$ Enrichment of both C and $\mathrm{Nb}$ in the inter-dendritic liquid phase leads to preferential precipitation of $\mathrm{NbC}$ at inter-dendritic boundaries (Figures 6 and 9).

Variables that control hot-ductility of steel include strain rate, grain size, precipitation, inclusion concentration $^{[8]}$ and matrix homogeneity. ${ }^{[16]}$ Increasing strain rates improves hot ductility by reducing amount of grain boundary sliding. Refinement of a grain size improves hot ductility by suppressing crack propagation along grain boundaries. ${ }^{[8]}$ Fine precipitates, in particular at grain boundaries, reduce hot ductility since the particles located close enough one another facilitate linking of cracks. ${ }^{[8]}$ Reduced matrix homogeneity characterized by pronounced micro-segregation and presence of micro-porosities also reduces hot ductility. ${ }^{[16]}$

Previous works on hot ductility of TWIP steels reported an increase of hot ductility with increasing strain rates. ${ }^{[12,13]}$ Increasing strain rates considerably to improve hot ductility of steel is generally not possible in conventional continuous casting. ${ }^{[8]}$ Lan et al. ${ }^{[16]}$ reported that a small grain size and weak micro-segregation improved hot ductility of a TWIP steel. The Mn segregation in inter-dendritic regions of high Mn steels led to low hot ductility due to the presence of zones that have low melting temperatures in the inter-dendritic areas. ${ }^{[10]}$

$\mathrm{Nb}$ addition slightly reduces hot ductility of the investigated steel at $1173 \mathrm{~K}\left(900{ }^{\circ} \mathrm{C}\right)$ (Figure 16). This is most likely due to fine $\mathrm{NbC}$ precipitates present at inter-dendritic boundaries, which could result in weakening of interfaces. The presence of fine $\mathrm{NbC}$ precipitates could also contribute to the higher peak stress of 


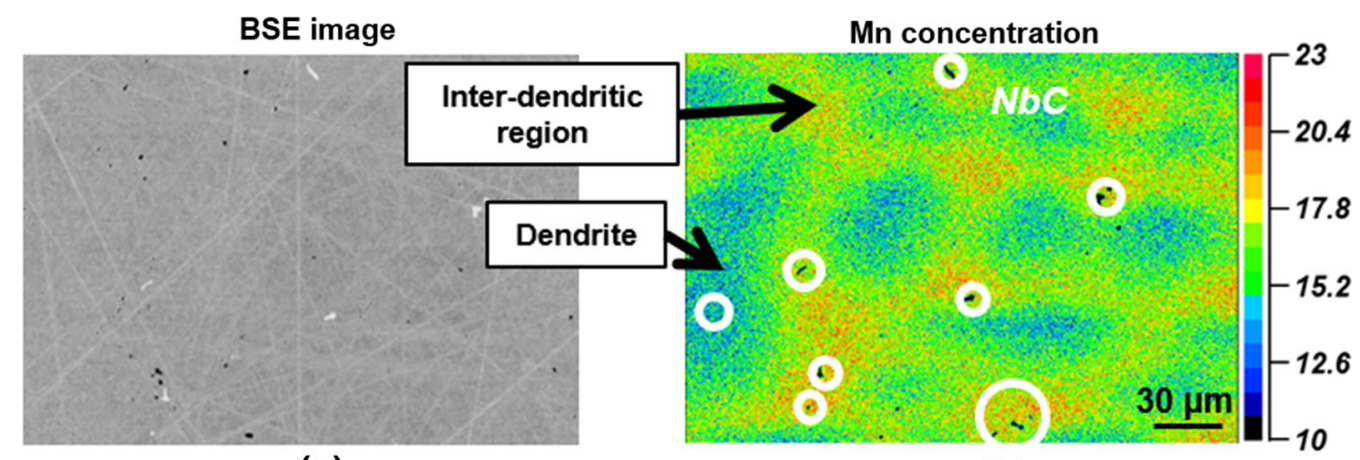

(a)

(b)

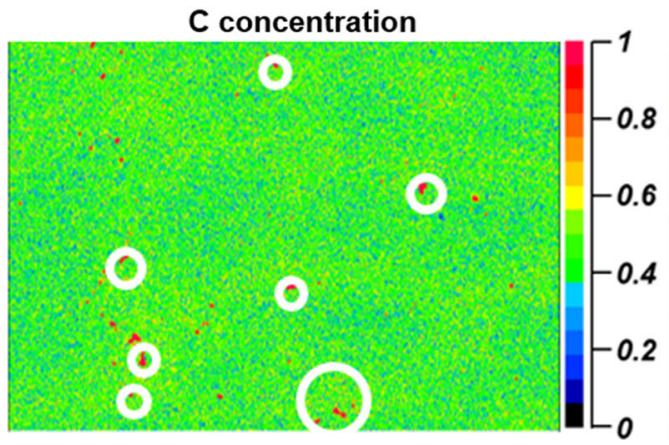

(c)

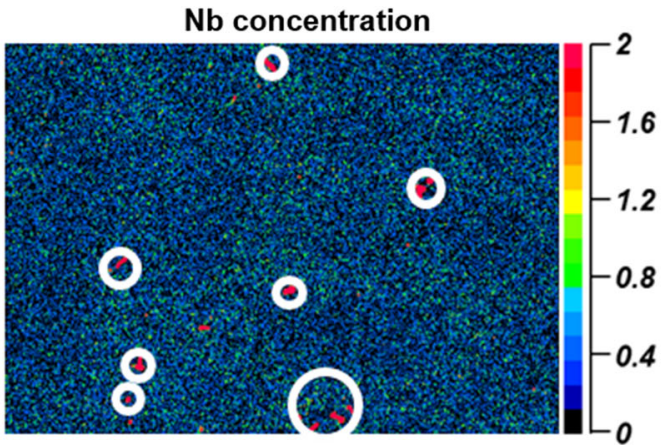

(d)

Fig. 9-(a) SEM backscattered electron (BSE) image and EPMA elemental distribution maps showing (b) Mn, $(c)$ C, and (d) Nb concentration in the as-cast $100 \mathrm{Nb}$ steel.

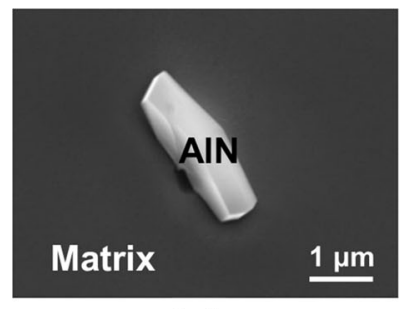

(a)

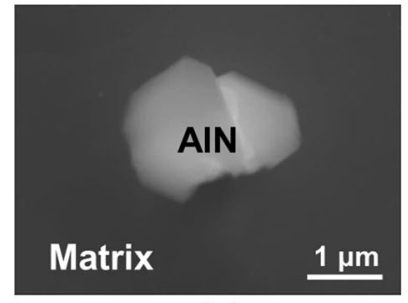

(c)
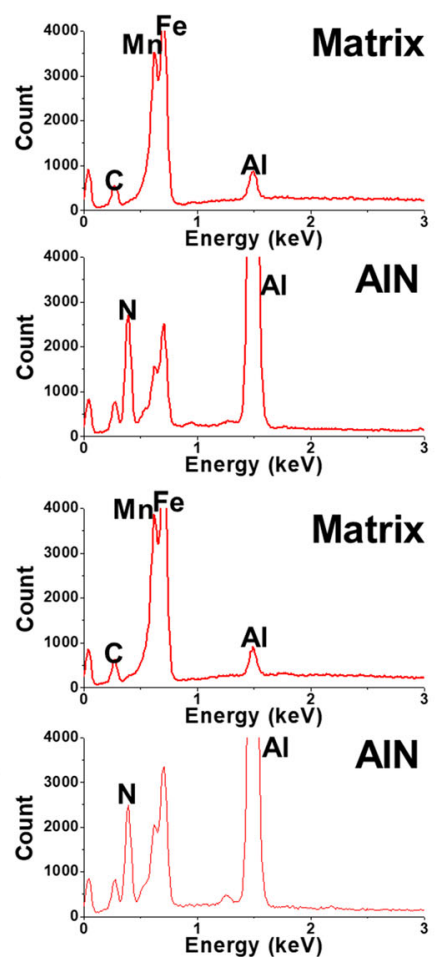
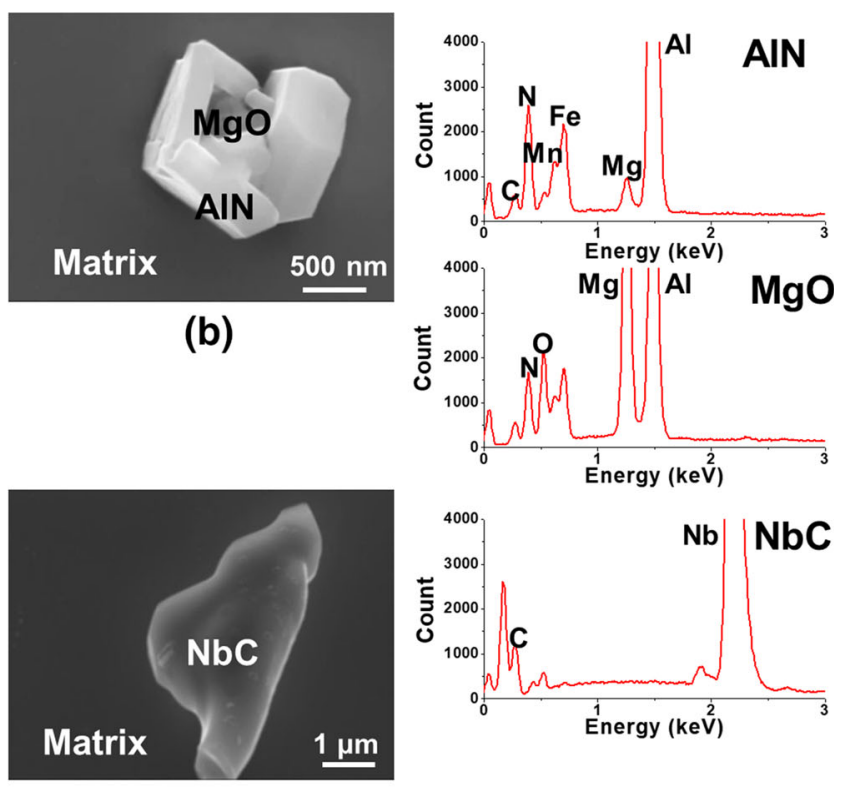

(d)

Fig. 10-Microstructure and corresponding composition of the precipitates: (a) AlN and (b) MgO surrounded by AlN in the Nb-free reference steel. (c) AlN and (d) $\mathrm{NbC}$ precipitates in the $100 \mathrm{Nb}$ steel. 


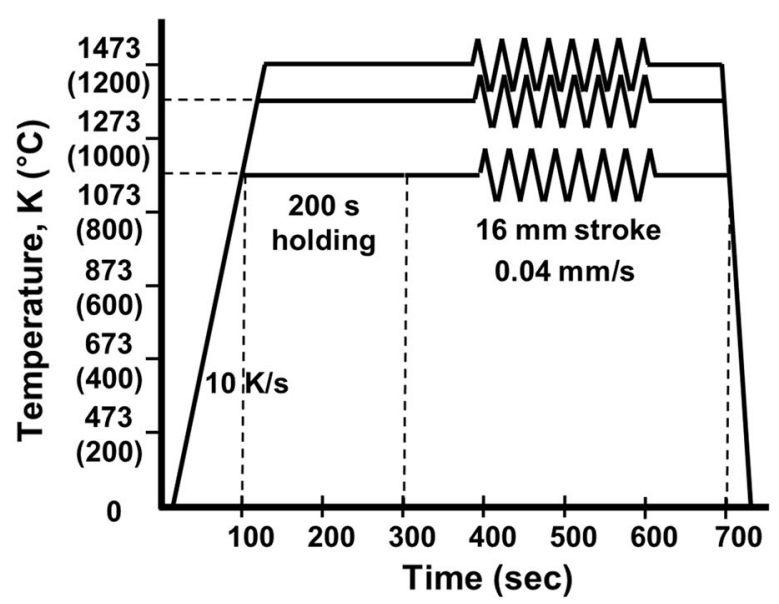

(a)

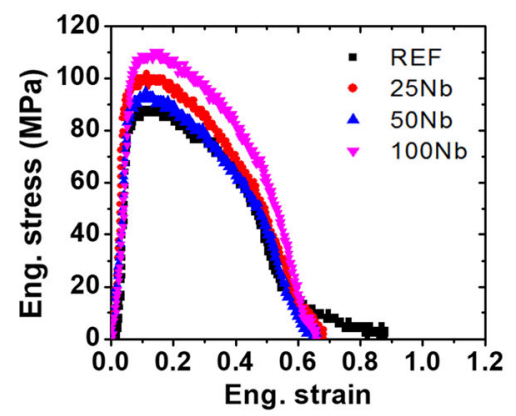

(b)

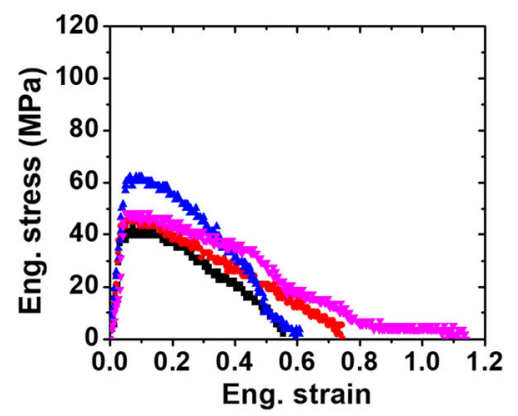

(c)

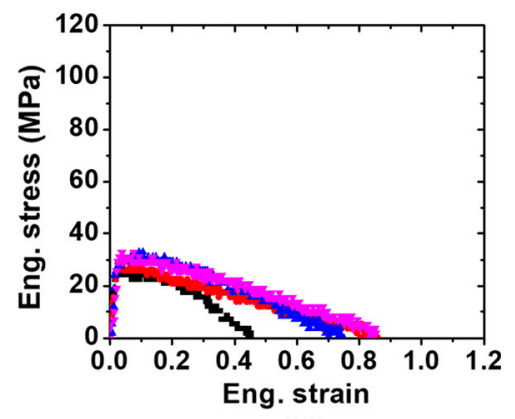

(d)

Fig. 11- (a) Details of procedures of high-temperature tensile tests. $(b)$ Stress-strain curves of the TWIP steels tested at $(b) 1173 \mathrm{~K}\left(900{ }^{\circ} \mathrm{C}\right)$, $(c)$ $1373 \mathrm{~K}\left(1100^{\circ} \mathrm{C}\right)$, and $(d) 1473 \mathrm{~K}\left(1200^{\circ} \mathrm{C}\right)$.

the Nb-added steels (Figure 11(b)). Mejia et al. ${ }^{[15]}$ mentioned that $\mathrm{Nb}$ addition resulted in a loss of hot ductility due to $\mathrm{NbC}$ precipitation at grain boundaries. According to them, grain boundary precipitation prevented dynamic recrystallization and led to grain boundary sliding. Since the quantity of $\mathrm{NbC}$ precipitates increases with increasing $\mathrm{Nb}$ concentration, $\mathrm{NbC}$ precipitation could result in low hot ductility at lower deformation temperatures. Deformation microstructures of the reference and $100 \mathrm{Nb}$ steel after deformation at $1173 \mathrm{~K}$ $\left(900{ }^{\circ} \mathrm{C}\right.$ ) were observed by TEM (Figures 17 (a) through (c)). Deformation microstructure of the reference steel shows homogeneous distribution of dislocations and the presence of low-angle boundaries indicated by white arrows (Figure 17(a)). Figures 17(b) and (c) show deformation microstructures of the $100 \mathrm{Nb}$ steel. Figure 17(b) shows homogeneous distribution of fine NbC precipitates while Figure 17(c) shows heterogeneous distribution of fine $\mathrm{NbC}$ precipitates. Some precipitates indicated by white arrows show a row-like characteristic, which are most likely interface precipitates. The average diameter of $\mathrm{NbC}$ precipitates in the $100 \mathrm{Nb}$ steel deformed at $1173 \mathrm{~K}\left(900^{\circ} \mathrm{C}\right)$ is approximately $15 \mathrm{~nm}$. The interaction between dislocations and $\mathrm{NbC}$ precipitates is evidenced by pinning of some dislocations by the precipitates. Compared to the reference steel, distribution of dislocations is more heterogeneous in the $100 \mathrm{Nb}$ steel. Therefore, presence

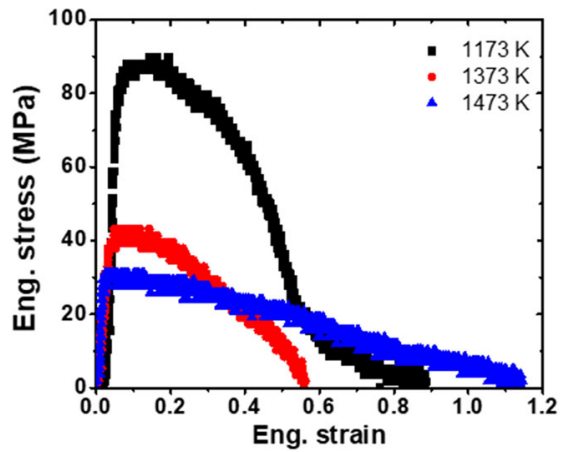

(a)

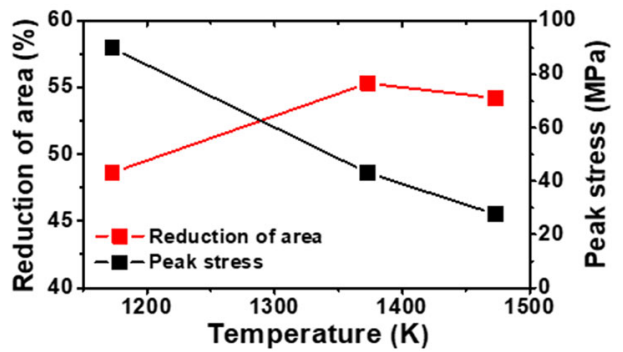

(b)

Fig. 12-(a) Stress-strain curves of the Nb-free reference steel tested at $1173 \mathrm{~K}\left(900{ }^{\circ} \mathrm{C}\right), 1373 \mathrm{~K}\left(1100{ }^{\circ} \mathrm{C}\right)$, and $1473 \mathrm{~K}\left(1200{ }^{\circ} \mathrm{C}\right) .(b)$ The peak stress and the reduction of area of the $\mathrm{Nb}$-free reference steel with respect to deformation temperatures. 


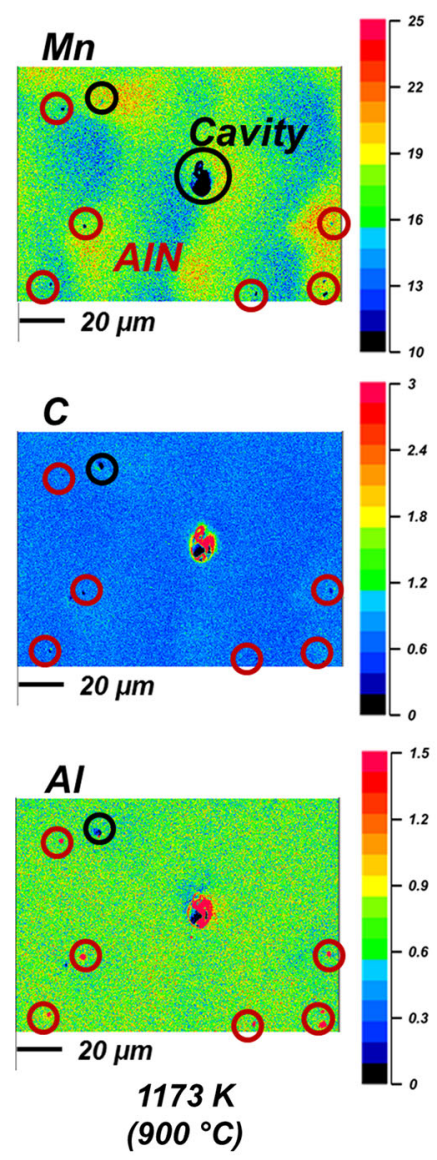

(a)
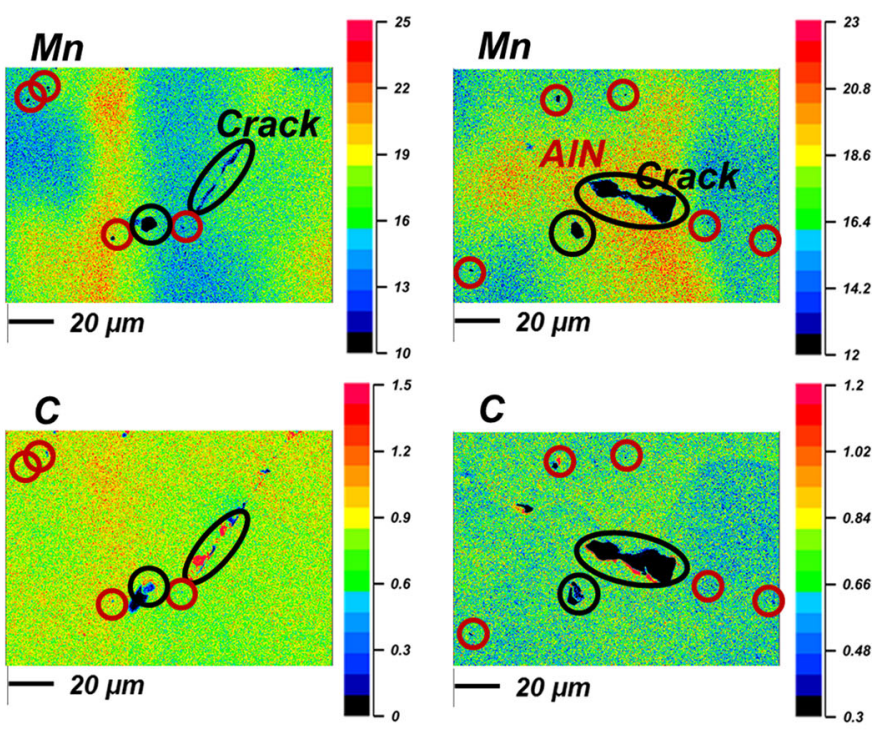

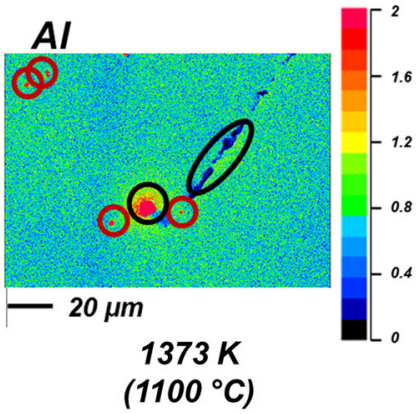

(b)

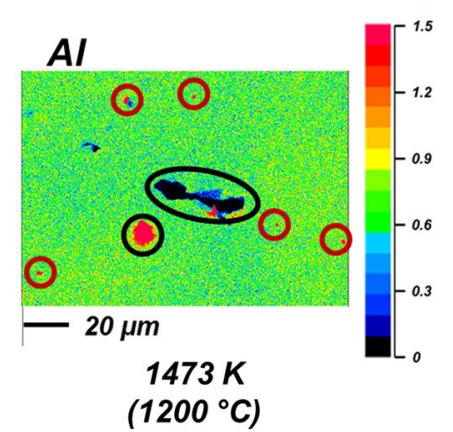

(c)

Fig. 13-EPMA elemental distribution maps of $\mathrm{Fe}, \mathrm{Mn}$, and $\mathrm{C}$ for the $\mathrm{Nb}$-free reference steel tested at $(a) 1173 \mathrm{~K}\left(900{ }^{\circ} \mathrm{C}\right)$, $(b) 1373 \mathrm{~K}$ $\left(1100^{\circ} \mathrm{C}\right)$, and $(c) 1473 \mathrm{~K}\left(1200^{\circ} \mathrm{C}\right)$.

of fine $\mathrm{NbC}$ precipitates and heterogeneous distribution of dislocations could affect decreased hot ductility of the Nb-added TWIP steels.

The Nb-added TWIP steels show better hot-ductility than the reference steel for deformation temperatures above $1373 \mathrm{~K}\left(1100{ }^{\circ} \mathrm{C}\right)$. As shown in Figures 13 and 15 , typical inter-dendritic distances are smaller in the $\mathrm{Nb}$-added steel as compared to the $\mathrm{Nb}$-free reference steel. $\mathrm{Nb}$ addition is known to inhibit grain growth, and a fine grain size is beneficial to hot-ductility of high $\mathrm{Mn}$ steels. ${ }^{[16]}$ In addition to the effect of dragging or pinning forces, $\mathrm{Nb}$ micro-alloying could increase thermal conductivity and decrease effective solidification time, which resulted in a decrease in secondary dendritic arm spacing. ${ }^{[36]}$ These combined effects can lead to refined solidification microstructures by $\mathrm{Nb}$ micro-alloying. Cracks are frequently observed in the Mn-enriched inter-dendritic regions (Figures 13 and 15). These cracks may propagate easily in the coarse inter-dendritic regions of the $\mathrm{Nb}$-free reference steel. $\mathrm{NbC}$ precipitates coarsen at high temperatures, and they could be less detrimental than fine precipitates. The presence of coarsened $\mathrm{NbC}$ precipitates could also result in similar peak stresses of the reference steel and the $\mathrm{Nb}$-added steels (Figure 11(d)). Figure 17(d) shows a deformation

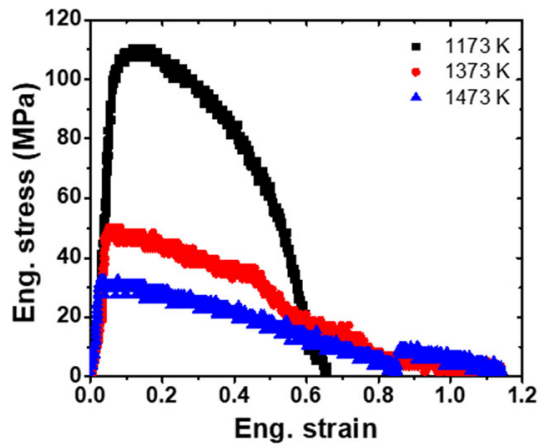

(a)

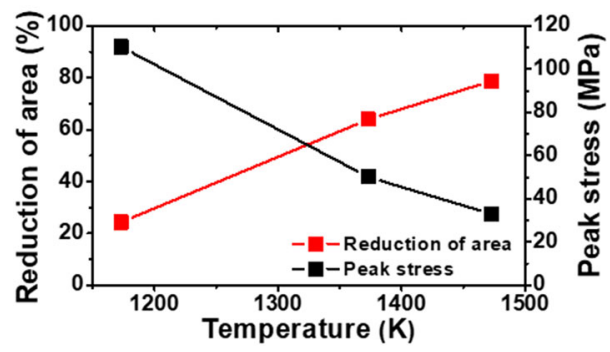

(b)

Fig. 14 - (a) Stress-strain curves of the $100 \mathrm{Nb}$ steel tested at $1173 \mathrm{~K}\left(900{ }^{\circ} \mathrm{C}\right)$, $1373 \mathrm{~K}\left(1100{ }^{\circ} \mathrm{C}\right)$, and $1473 \mathrm{~K}\left(1200{ }^{\circ} \mathrm{C}\right)$. (b) The peak stress and the reduction of area of the $100 \mathrm{Nb}$ steel with respect to deformation temperatures. 

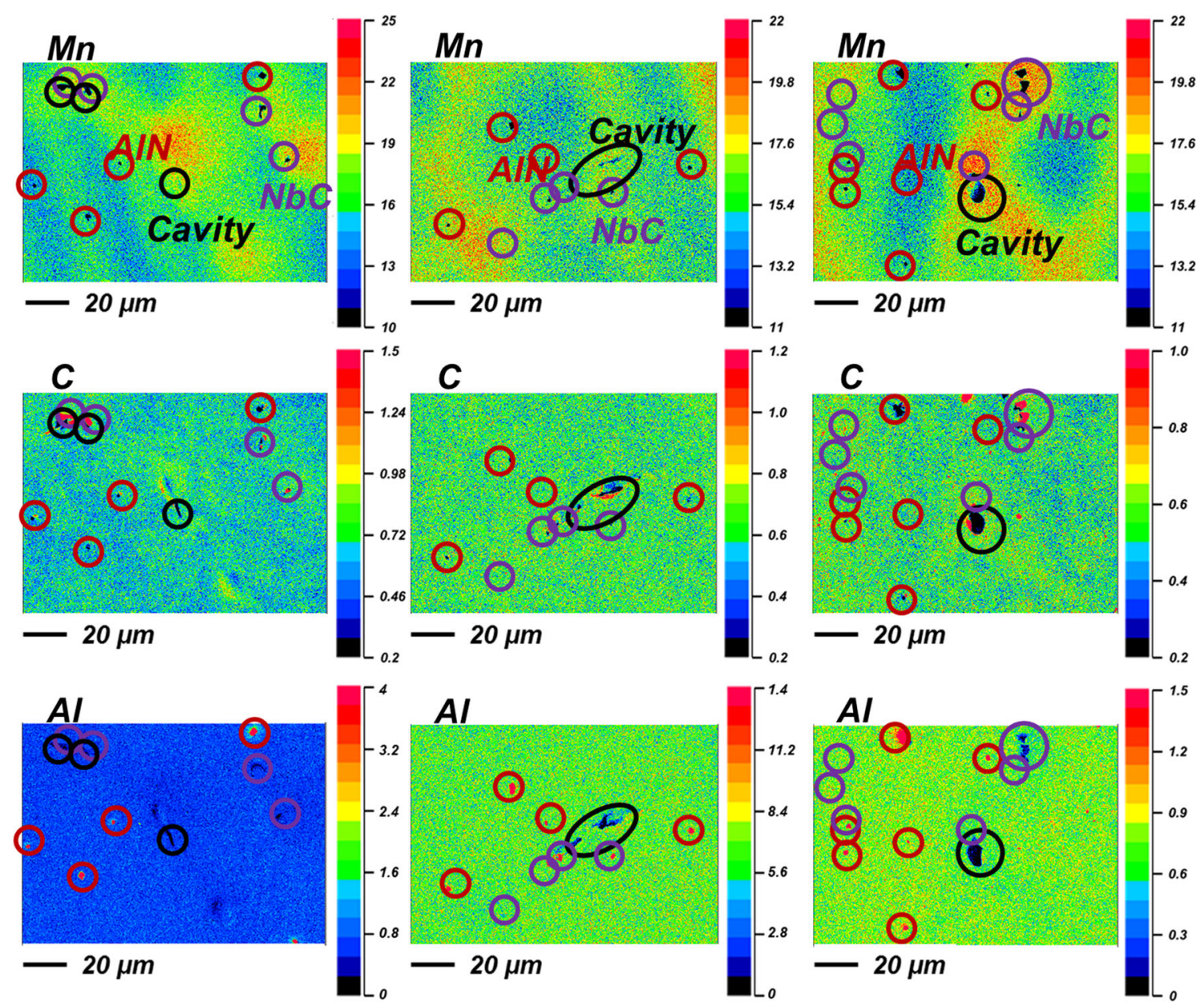

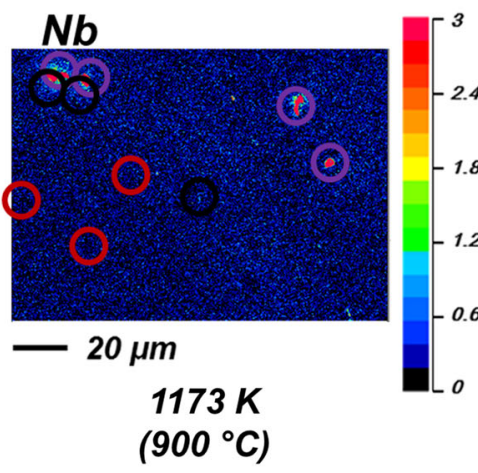

(a)

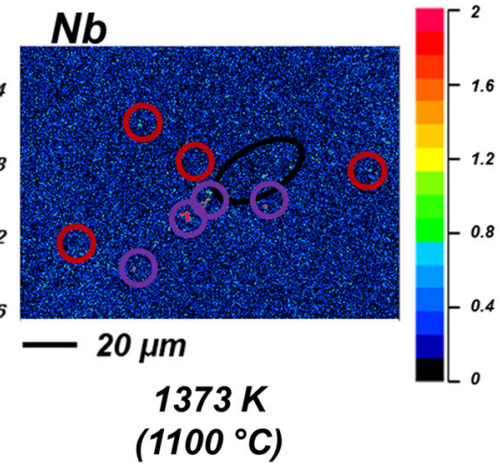

(b)

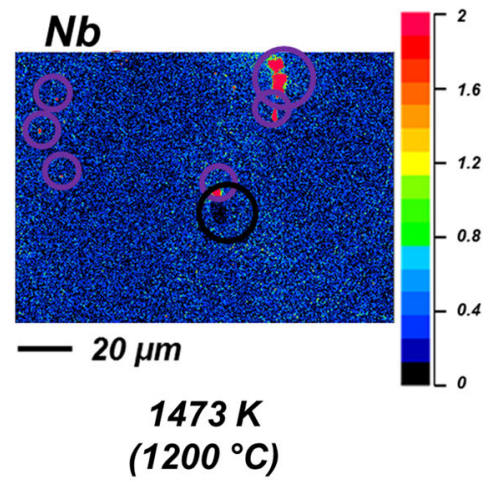

(c)

Fig. 15-EPMA elemental distribution maps of $\mathrm{Fe}, \mathrm{Mn}, \mathrm{Al}$, and $\mathrm{C}$ in the $100 \mathrm{Nb}$ steel tested at $(a) 1173 \mathrm{~K}\left(900{ }^{\circ} \mathrm{C}\right),(b) 1373 \mathrm{~K}\left(1100{ }^{\circ} \mathrm{C}\right)$, and (c) $1473 \mathrm{~K}\left(1200^{\circ} \mathrm{C}\right)$.

microstructure of the $100 \mathrm{Nb}$ steel deformed at $1473 \mathrm{~K}$ $\left(1200{ }^{\circ} \mathrm{C}\right)$. Dislocation density of the $100 \mathrm{Nb}$ steel deformed at $1473 \mathrm{~K}\left(1200{ }^{\circ} \mathrm{C}\right)$ is much lower than that at $1173 \mathrm{~K}\left(900{ }^{\circ} \mathrm{C}\right)$. Some dislocations are pinned by the $\mathrm{NbC}$ precipitates. The $\mathrm{NbC}$ precipitates in the material deformed at $1473 \mathrm{~K}\left(1200{ }^{\circ} \mathrm{C}\right)$ are coarser than that at $1173 \mathrm{~K}\left(900{ }^{\circ} \mathrm{C}\right)$. The average diameter of $\mathrm{NbC}$ precipitates in the $100 \mathrm{Nb}$ steel deformed at $1473 \mathrm{~K}\left(1200{ }^{\circ} \mathrm{C}\right)$ is approximately $40 \mathrm{~nm}$. Both effects, i.e., fine interdendritic areas and coarsened $\mathrm{NbC}$ precipitates, therefore explain the increased hot ductility in the $\mathrm{Nb}$-added TWIP steels tested at high temperatures.

Dynamic recrystallization (DRX) is an important phenomenon affecting hot deformation behavior of high Mn steels. ${ }^{[14]}$ In the present case, however, effect of DRX on hot-ductility of the investigated steels is very limited. EBSD analyses of deformation microstructures at $1473 \mathrm{~K}\left(1200{ }^{\circ} \mathrm{C}\right)$ showed that fraction of recrystallized grains is less than 0.005 for both the reference steel and the $100 \mathrm{Nb}$ steel. The absence of DRX is closely 
related to composition of TWIP steels. Liu et al. ${ }^{[17]}$ reported that TWIP steels with high Mn content inhibited DRX and promoted grain boundary sliding during high-temperature tensile tests, which decreased hot ductility of the TWIP steels. They also reported that

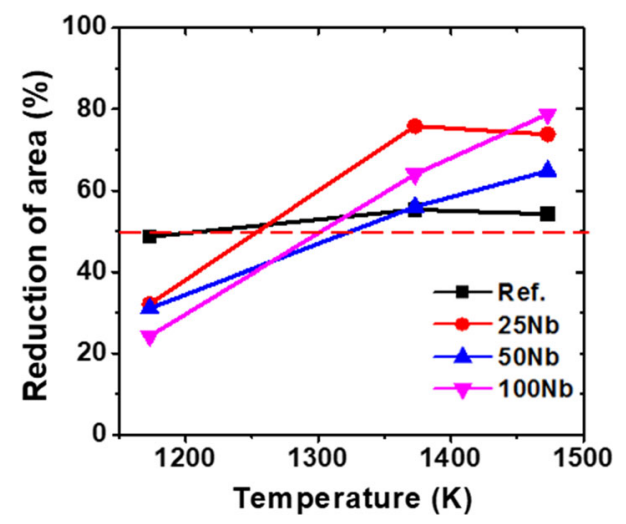

Fig. 16-Deformation temperature dependence of the reduction of area for the investigated TWIP steels.
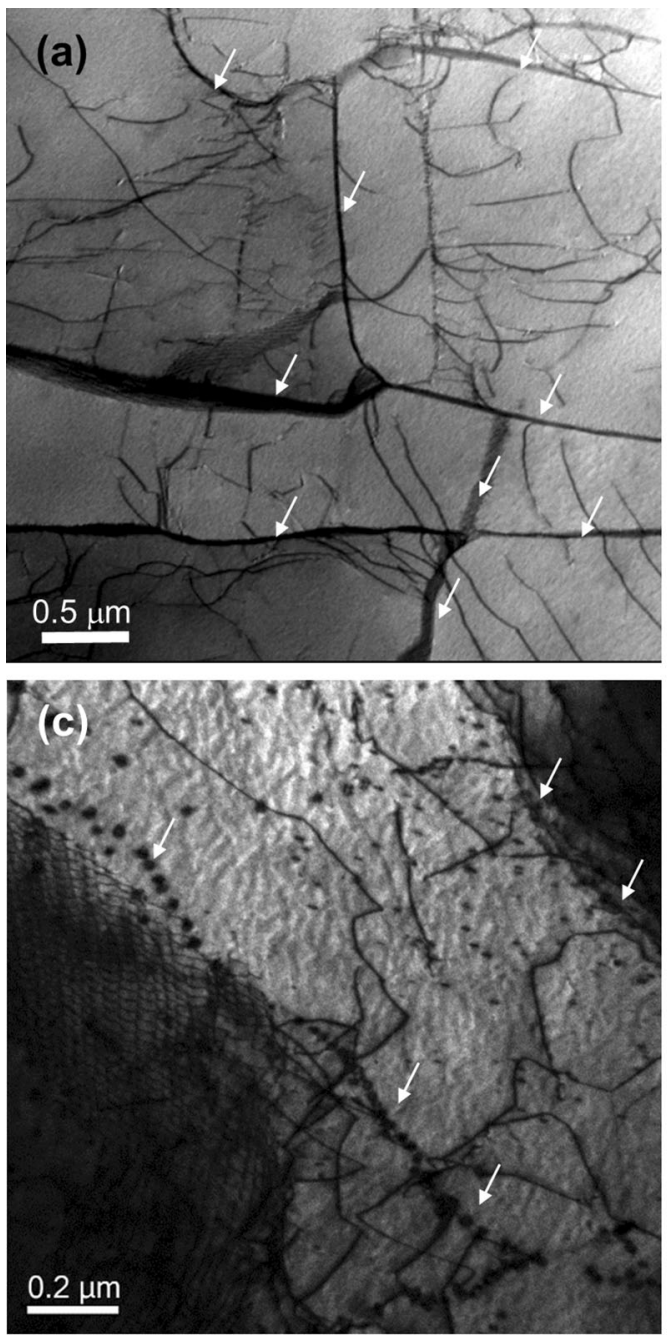

no DRX grains were observed in the Al-added TWIP steels. This is consistent with the present work that the investigated Al-added TWIP steels with high Mn content does not show significant DRX during high-temperature tensile tests.

\section{CONCLUSIONS}

In this study, we investigated effect of $\mathrm{Nb}$ addition on casting microstructures and high-temperature mechanical properties of $\mathrm{Fe}-\mathrm{Mn}-\mathrm{C}-\mathrm{Al}-\mathrm{xNb}$ TWIP steels using both phase-field simulations and experiments. We draw the following conclusions:

1. Phase-field simulations showed that $\mathrm{Mn}, \mathrm{Nb}$, and $\mathrm{C}$ are enriched in inter-dendritic regions while $\mathrm{Al}$ is enriched in dendritic regions during solidification of the investigated TWIP steels. Both phase-field simulations and experimental characterizations show that $\mathrm{NbC}$ precipitates are preferentially present near inter-dendritic boundaries.
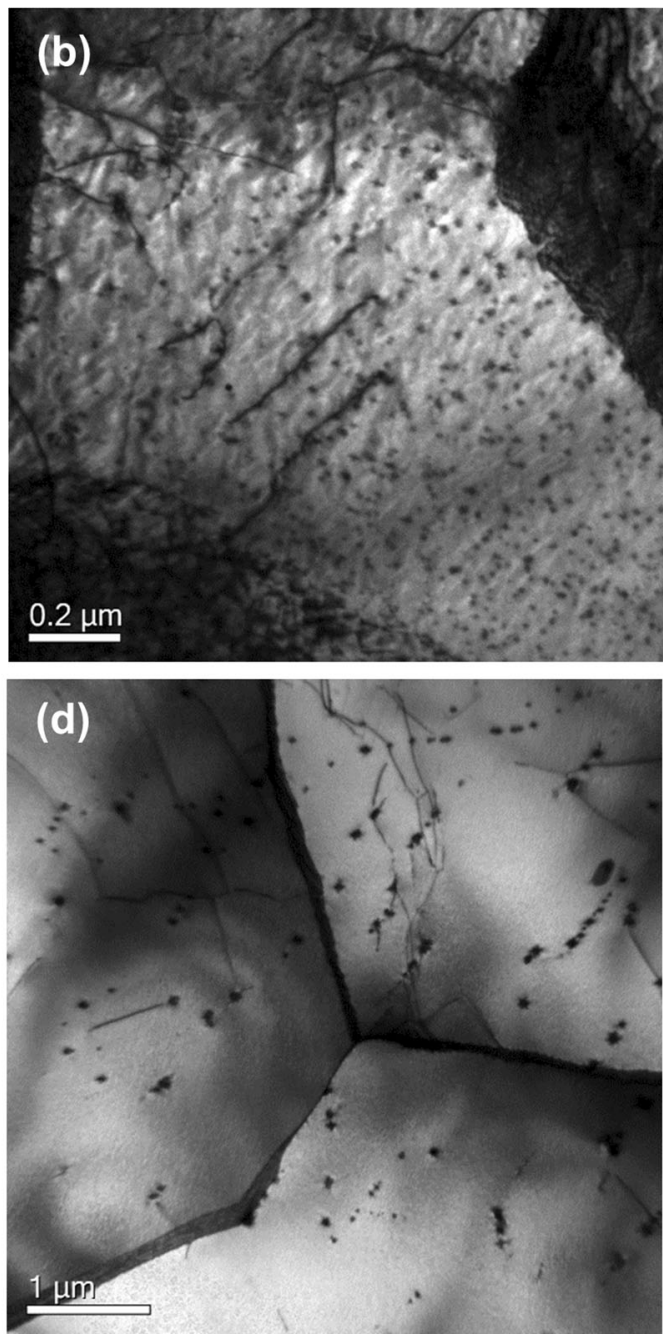

Fig. 17-TEM deformation microstructures of the $(a)$ reference, $(b, c) 100 \mathrm{Nb}$ steel after deformation at $1173 \mathrm{~K}\left(900{ }^{\circ} \mathrm{C}\right)$, and $(d) 100 \mathrm{Nb}$ steel after deformation at $1473 \mathrm{~K}\left(1200^{\circ} \mathrm{C}\right)$. 
2. $\mathrm{Nb}$ addition slightly reduces hot ductility of the investigated steel at $1173 \mathrm{~K}\left(900{ }^{\circ} \mathrm{C}\right)$. The presence of fine $\mathrm{NbC}$ precipitates and heterogeneous distribution of dislocations most likely result in the slight reduction in hot ductility.

3. The Nb-added TWIP steels show better hot-ductility than the reference steel for deformation temperatures above $1373 \mathrm{~K} \quad\left(1100{ }^{\circ} \mathrm{C}\right)$. Typical inter-dendritic distances are smaller in the $\mathrm{Nb}$-added steel as compared to the $\mathrm{Nb}$-free reference steel. Easy propagation of cracks in the coarse inter-dendritic regions of the $\mathrm{Nb}$-free reference steel could result in worse hot-ductility of the reference steel. In addition, $\mathrm{NbC}$ precipitates coarsen at high temperatures, and they could be less detrimental to hot ductility than fine precipitates.

\section{ACKNOWLEDGMENTS}

The authors gratefully acknowledge the support of CBMM and the POSCO Technical Research Laboratories.

\section{REFERENCES}

1. O. Grässel, L. Krüger, G. Frommeyer, and L. Meyer: Inter. J. Plast., 2000, vol. 16, pp. 1391-09.

2. G. Frommeyer, U. Brüx, and P. Neumann: ISIJ Int., 2003, vol. 43, pp. $438-46$.

3. O. Bouaziz, S. Allain, C. Scott, P. Cugy, and D. Barbier: Curr. Opin. Solid State Mater. Sci., 2011, vol. 5, pp. 141-68.

4. B.C. De Cooman, Y. Estrin, and S.K. Kim: Acta Mater., 2018, vol. 142 , pp. $283-62$.

5. O. Bouaziz and N. Guelton: Mater. Sci. Eng. A, 2001, vols. 319-321, pp. 246-49.

6. J. Kim, Y. Estrin, and B.C. De Cooman: Metall. Mater. Trans. A, 2013, vol. 44A, pp. 4168-82.

7. J.-K. Kim and B.C. De Cooman: Mater. Sci. Eng. A, 2016, vol. 676 , pp. $216-31$

8. B. Mintz: ISIJ Int., 1999, vol. 39, pp. 833-55.

9. A. Rezaeian, F. Zarandi, and S. Yue: Metall. Mater. Trans. A, 2008, vol. 39A, pp. 2635-44.

10. W. Bleck, K. Phiu-on, C. Heering, and G. Hirt: Steel Res. Int., 2007 , vol. 78 , pp. $536-45$
11. A.S. Hamada and L.P. Karjalainen: Mater. Sci. Eng. A, 2011, vol. 528, pp. 1819-27.

12. S.E. Kang, A. Tuling, J.R. Banerjee, W.D. Gunawardana, and B. Mintz: Mater. Sci. Technol., 2011, vol. 27, pp. 95-100.

13. K. Han, J. Yoo, B. Lee, I. Han, and C. Lee: Mater. Sci. Eng. A, 2014, vol. 618A, pp. 295-304.

14. I. Mejía, A. Salas-Reyes, A. Bedolla-Jacuinde, J. Calvo, and J. Cabrera: Mater. Sci. Eng. A, 2014, vol. 616, pp. 229-39.

15. I. Mejía, A.E. Salas-Reyes, J. Calvo, and J.M. Cabrera: Mater. Sci. Eng. A, 2015, vol. 648, pp. 311-29.

16. P. Lan, H. Tang, and J. Zhang: Mater. Sci. Eng. A, 2016, vol. 660, pp. $127-38$.

17. H. Liu, J. Liu, B. Wu, Y. Shen, Y. He, H. Ding, and X. Su: Mater. Sci. Eng. A, 2017, vol. 708, pp. 360-74.

18. S.E. Kang, A. Tuling, I. Lau, J.R. Banerjee, and B. Mintz: Mater. Sci. Technol., 2011, vol. 27, pp. 909-15.

19. S.E. Kang, J.R. Banerjee, and B. Mintz: Mater. Sci. Technol., 2012, vol. 28, pp. 589-96.

20. S.E. Kang, J.R. Banerjee, E.M. Maina, and B. Mintz: Mater. Sci. Technol., 2013, vol. 29, pp. 1225-32.

21. S.E. Kang, J.R. Banerjee, A.S. Tuling, and B. Mintz: Mater. Sci. Technol., 2014, vol. 30, pp. 486-94.

22. S.E. Kang, J.R. Banerjee, A. Tuling, and B. Mintz: Mater. Sci. Technol., 2014, vol. 30, pp. 1328-35.

23. C. Scott, B. Remy, J.-L. Collet, A. Cael, C. Bao, F. Danoix, B. Malard, and C. Curfs: InterJ. Mater. Res., 2011, vol. 102, pp. $538-49$.

24. D. Li, Y. Feng, S. Song, Q. Liu, Q. Bai, G. Wu, N. Lv, and F. Ren: Mater. Des., 2015, vol. 84, pp. 238-44.

25. H. Gwon, J.-K. Kim, S. Shin, L. Cho, and B.C. De Cooman: Mater. Sci. Eng. A, 2017, vol. 696, pp. 416-28.

26. H. Gwon, J.-K. Kim, B. Jian, H. Mohrbacher, T. Song, S.-K. Kim, and B.C. De Cooman: Mater. Sci. Eng. A, 2018, vol. 711, pp. 130-39.

27. B. Böttger, M. Apel, B. Santillana, and D.G. Eskin: IOP Conf. Series: Mater. Sci. Eng., 2012, vol. 33, pp. 1-8.

28. C. Beckermann, H.-J. Diepers, I. Steinbach, A. Karma, and X. Tong: J. Comput. Phys., 1999, vol. 154, pp. 468-96.

29. B. Böttger, J. Eiken, and I. Steinbach: Acta Mater., 2006, vol. 54, pp. 2697-04

30. B. Böttger, M. Apel, B. Santillana, and D.G. Eskin: Metall. Mater. Trans. A, 2013, vol. 44A, pp. 3765-77.

31. B. Böttger, J. Eiken, and M. Apel: J. Comp. Phys, 2009, vol. 228, pp. 6784-95.

32. G. Krauss: Metall. Mater. Trans. B, 2003, vol. 34B, pp. 781-92.

33. M. Sharma, S. Richter, U. Prahl, and W. Bleck: Steel Res. Int., 2017, vol. 88, p. 1700092.

34. D. Chakrabarti, C. Davis, and M. Strangwood: Metall. Mater. Trans. A, 2008, vol. 39A, pp. 1963-77.

35. B.L. Ennis, E. Jimenez-Melero, R. Mostert, B. Santillana, and P.D. Lee: Acta Mater., 2016, vol. 115, pp. 132-42.

36. X. Gao, S. Yang, and J. Li: Mater. Des., 2016, vol. 110, pp. 284-95. 